\title{
Kajian Perbandingan Akurasi DTM Pengolahan Data Foto Udara Menggunakan Metode Otomatis Dan Semi-Otomatis Filtering
}

\author{
Raynier Geraldino Dadu Kerong ${ }^{1}$, Martinus Edwin Tjahjadi ${ }^{1}$ (D), Fransisca Dwi Agustina ${ }^{1}$ (D) \\ ${ }^{1}$ Program Studi Teknik Geodesi, Institut Teknologi Nasional Malang, Jl.Sigura-gura No.2, Kota Malang 65152, \\ Indonesia
}

\section{ARTICLE INFO}

Article history:

Received: 17 November 2021

Accepted: 21 January 2022

Published: 29 January 2022

Keywords:

Automatic Filtering; DTM; Semi-

Automatic Filtering; Spot-Height; UAV

Corresponding author:

Raynier Geraldino Dadu Kerong

Email: rayniergeraldino@gmail.com

\section{Read online:}

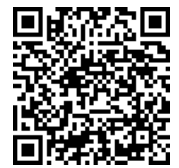

Scan this QR code with your smart phone or mobile device to read online.

\begin{abstract}
Advances in UAV technology produce various superior products that can be utilized for the development and analysis of natural dynamics. One of them is DTM which is a visual representation of the shape of the ground surface that is displayed in 3 dimensions. DTM is obtained from the results of DSM filtering, where all features above the ground are digitally removed using a certain method. To produce a good DTM, a good quality DSM is needed, therefore a Horizontal and Vertical accuracy analysis was carried out based on ASPRS 2015. In this study, two software with different data processing methods were used, namely automatic filtering and semiautomatic filtering from DSM to DTM. To determine the quality of DTM, spot-height data is used as a comparison which is considered to be the actual form in the field. From the series of data processing processes, DTM results were obtained which were then tested for accuracy utilizing statistical validation tests using the calculation of RMSEZ values and non-statistical validation tests (Visual) using the transverse profile method. The test results show that the DTM produced by the PCI Geomatica software with the semi-automatic filtering method has more accurate and precise quality than the DTM from the SAGA GIS software with the automatic filtering method with an elevation value of $1,249 \mathrm{~m}$ and RMSEz 3,542 $\mathrm{m}$ to the spot-height. Then the visualization of the DTM transverse profile produced by the PCI Geomatica software semi-automatic filtering method to the spot height also does not appear to experience a significant difference where the elevation at Point 1 is $0.5 \mathrm{~m}$ and Point 2 is $0.5 \mathrm{~m}$.
\end{abstract}

How to cite: Kerong, R. G. D., Tjahjadi, M. E., \& Agustina, F. D. (2022). Kajian Perbandingan Akurasi DTM Pengolahan Data Foto Udara Menggunakan Metode Otomatis Dan Semi-Otomatis Filtering. Jambura Geoscience Review, 4(1), 69-85. https://doi.org/10.34312/jgeosrev.v4i1.12046

\section{PENDAHULUAN}

Kemajuan teknologi Unmanned Aerial Vehicle (UAV) dengan kamera non-metrik sangat membantu dalam pekerjaan pemetaan dibidang foto udara. Namun, pemanfaatan foto udara dengan kamera non-metrik memiliki keterbatasan pada Interior Orientation Parameter (IOP) yang tidak stabil. Keterbatasan tersebut diantaranya adalah pengaruh angin saat terbang, yang berpotensi terjadi drift dan perbedaan skala. Hal ini juga berpengaruh pada area cakupan yang kecil, sehingga tidak mendukung untuk dilakukan pemrosesan secara fotogrametri analitik, seperti pemrosesan pada foto udara metrik. Alternatif lain yang dapat dilakukan yaitu dengan menerapkan teknologi fotogrametri digital, dengan kombinasi antara teknologi fotogrametri dan komputer vision (Riadi, 2015). Teknologi fotogrametri digital yang digunakan adalah sebuah software untuk memproses metadata foto udara dari UAV. Perangkat lunak ini menghasilkan berbagai produk fotogrametri digital, salah satu contohnya adalah Digital Terrain Model (DTM). DTM merupakan 
bentuk digital dari permukaan tanah, yang tidak ada objek di atasnya. Selain itu, merupakan representasi tiga dimensi permukaan tanah yang terdiri dari koordinat $\mathrm{x}, \mathrm{y}$, dan $\mathrm{z}$. Koordinat tersebut disimpan ke dalam bentuk digital yang mencakup unsur-unsur geografis dan fitur alami seperti sungai, jalur pegunungan, dan lain-lain (Duantari et al., 2017).

Berkembangnya ilmu pengetahuan, mendorong penemuan software yang mampu mengolah metadata foto udara menjadi DTM. Namun, masing-masing software tersebut memiliki tingkat akurasi yang berbeda-beda, terutama dalam menghasilkan DTM secara akurat dan presisi. Dikarenakan beda software berbeda juga metode pengolahannya, ada yang diproses secara otomatis filtering, ada yang diproses secara manual filtering, dan ada yang diproses secara semi-otomatis filtering. Sementara itu beberapa dekade ini semakin banyak pekerjaan dibidang fotogrametri yang menuntut kinerja dalam menghasilkan kualitas DTM yang akurat dan presisi.

Berdasarkan penelitian-penelitian sebelumnya (Martiana et al., 2017; Franstein et al., 2019; Wirantiko et al., 2020) software yang sering digunakan dan terbukti dapat menghasilkan DTM yang presisi adalah software dengan metode pengolahan otomatis filtering. Akan tetapi DTM hasil dari software dengan metode otomatis filtering ini belum menunjukan kemiripan atau keakuratan yang mendekati DTM Stereoplotting yang digunakan sebagai benchmark-nya. Dikarenakan kekurangan software tersebut penulis menggunakan sebuah software dengan metode berbeda yaitu software dengan metode pengolahan semi-otomatis filtering sebagai pembandingnya. Software ini sudah sangat sering digunakan baik itu di dalam maupun di luar negeri namun hanya untuk pembuatan orthophoto dan jarang digunakan untuk pembuatan DTM, akan tetapi berdasarkan penelitian (Muhammad \& Tahar, 2021; Pepe et al., 2021) terbukti software dengan metode pengolahan semiotomatis filtering juga dapat menghasilkan DTM yang presisi.

Penelitian ini fokus mengkaji perbandingan akurasi DTM, antara hasil pengolahan data otomatis filtering dengan data semi-otomatis filtering. Perbadingan ini dilakukan terhadap hasil pengukuran Spotheight (nilai ketinggian tanah) yang dianggap sebagai bentuk sebenarnya di lapangan. Sebelum hal tersebut dilakukan, diperlukan proses menganalisis ketelitian Digital Surface Model (DSM) berdasarkan standar American Society for Photogrammetry and Remote Sensing (ASPRS). DSM merupakan representasi suatu permukaan fisik dari sekumpulan titik-titik koordinat tiga dimensi. Data hasil DSM berisi vegetasi, jalan, bangunan, dan fitur medan alami. DSM digunakan untuk membentuk DTM dengan membuang semua fitur pada permukaan area secara digital (Duantari et al., 2017).

Tujuan dari penelitian ini adalah untuk mengetahui DTM yang lebih presisi dan akurat. Penelitian ini dapat menjadi rekomendasi bagi surveyor dalam memanfaatkan software yang tepat untuk menghasilkan DTM Presisi. Software yang memiliki akurasi DTM yang tinggi dapat digunakan sebagai dasar pemetaan dan analisis bencana alam.

\section{METODE}

\subsection{Lokasi Penelitian dan Tahapan Pengumpulan Data}

Penelitian ini berlokasi di daerah dekat Waduk Selorejo, Desa Pandansari, Kecamatan Ngantang, Kabupaten Malang, Jawa Timur (Gambar 1). Secara geografis Desa Pandansari terletak di 751'57,58” LS dan 112²1'39,68” BT. Area penelitian ini terletak pada ketinggian 555657 meter dari permukaan laut. Luas lokasi penelitian mencapai $( \pm 25 \mathrm{Ha})$, daerah ini dipilih karena tingkat vegetasinya yang rendah serta konturnya yang bervariasi. Data yang digunakan dalam penelitian ini merupakan data yang diperoleh secara langsung dengan pengukuran di lapangan. Persiapan dan pengumpulan data GPS, spotheight, dan foto udara dalam penelitian ini merupakan 3 bagian utama.

\subsubsection{Persiapan dan Pengumpulan Data GPS}

Tahapan ini bertujuan untuk memperoleh data GPS, yaitu data koordinat GCP dan koordinat ICP. Sebelum melakukan pengambilan data, dilakukan persiapan terlebih dahulu diantaranya adalah penentuan jumlah GCP. Peneliti menetapkan 4 titik patok beton dengan mengacu pada Peraturan BIG No.1 Tahun 2020. Patok ini sebelumnya telah dibuat dan juga memanfaatkan patok-patok yang sudah ada di lokasi penelitian seperti pada Gambar 2. Titik GCP tersebar pada area penelitian, yaitu terletak pada pojok, perimeter, dan tengah area pekerjaan (BIG, 2020). 

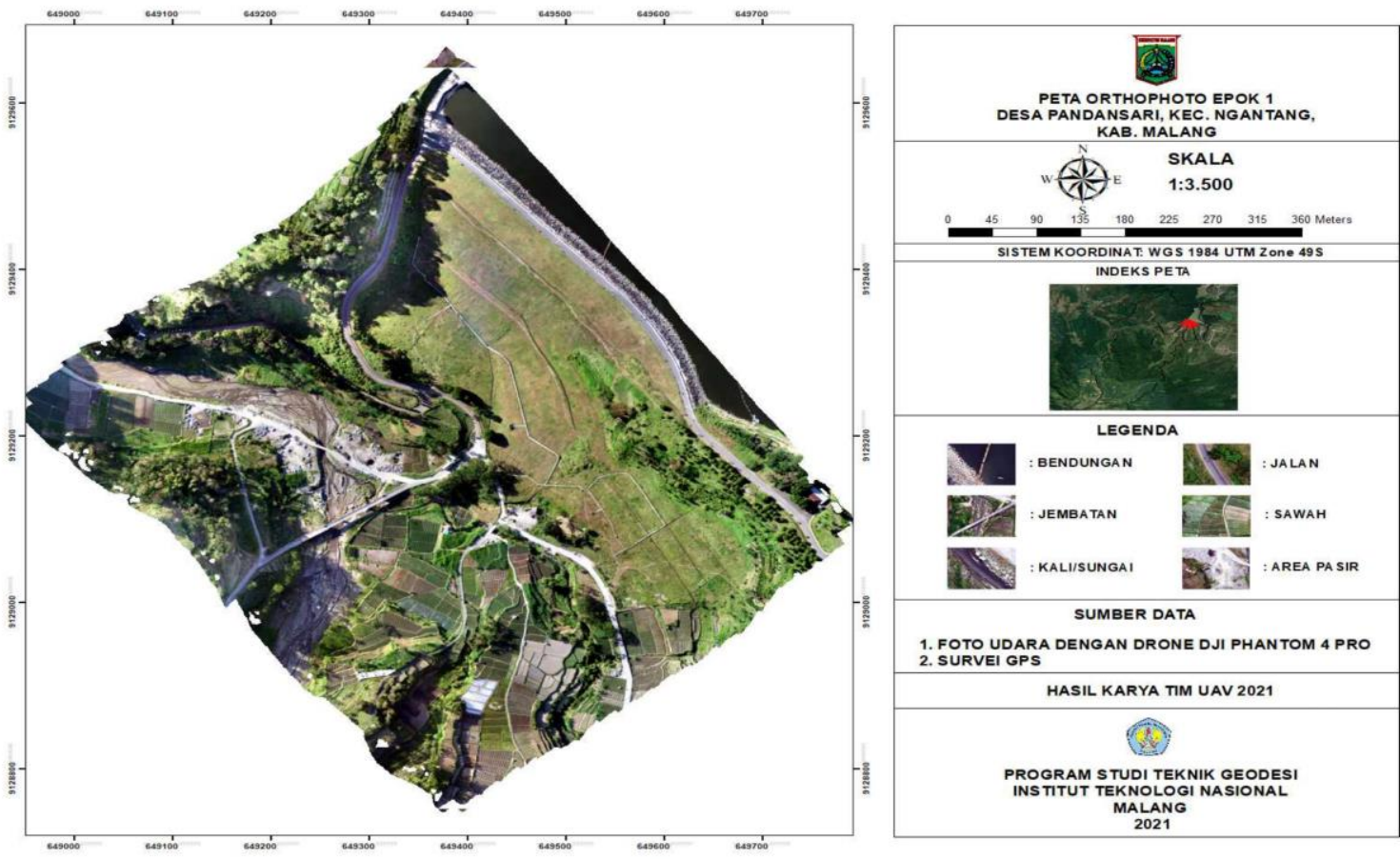

Gambar 1. Peta lokasi penelitian
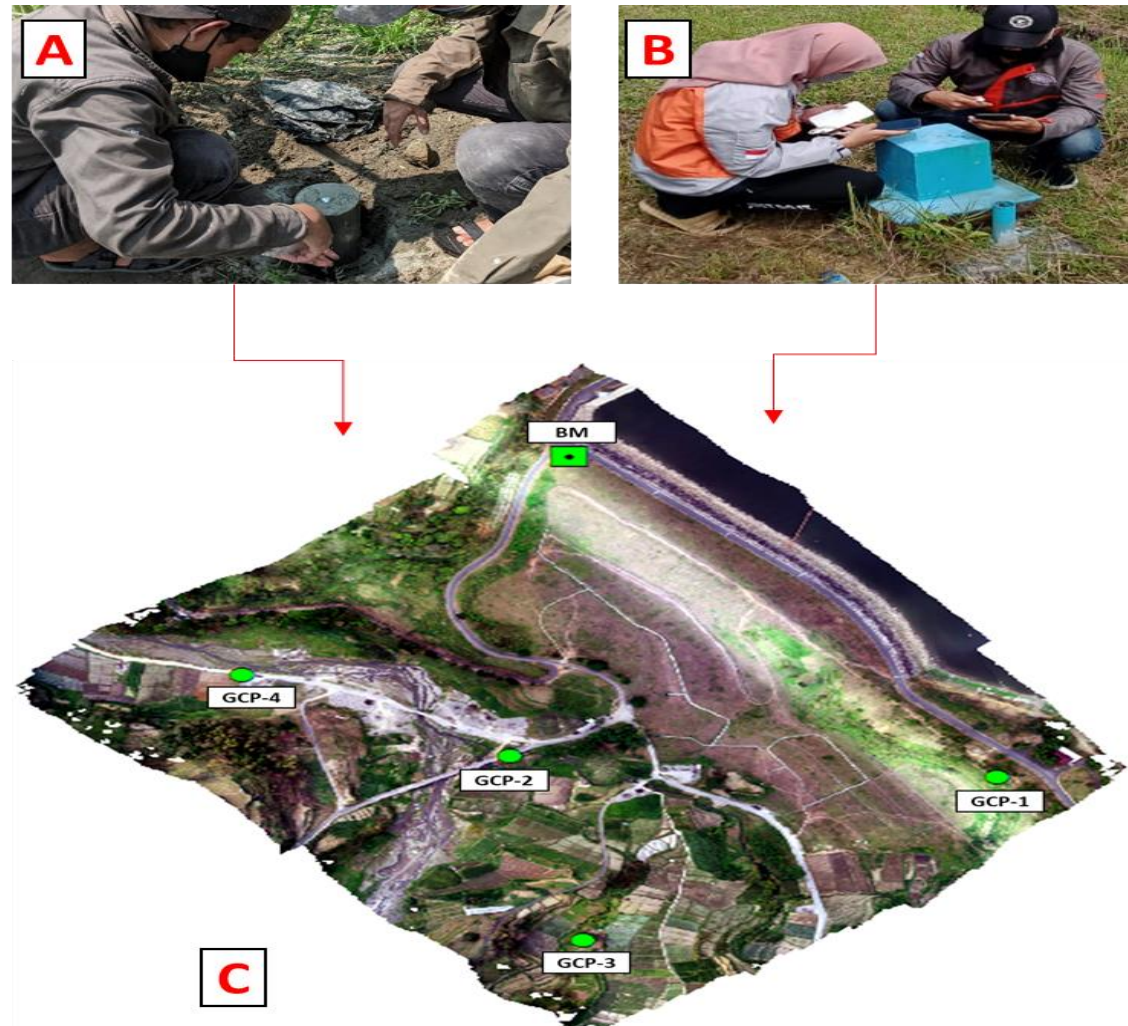

Gambar 2. (a) patok yang dibuat sendiri, (b) patok yang sudah ada di area penelitian, (c) persebaran titik GCP

Pengambilan data GCP menggunakan GPS Comnav T300 metode rapit static, dengan lama pengamatan 30 menit pada setiap titik/patok GCP (Khomsin et al., 2019). Pengamatan ini menggunakan 3 receiver, dimana terdapat koordinat titik tetap/BM pada daerah penelitian. Selanjutnya, dilakukan pengamatan secara bersamaan dengan base tetap pada BM dan 2 rover pada titik GCP 1 dan GCP 2 kemudian Rover pindah ke titik GCP 3 dan GCP 4. Pengamatan ini menghasilkan 4 data titik koordinat. 


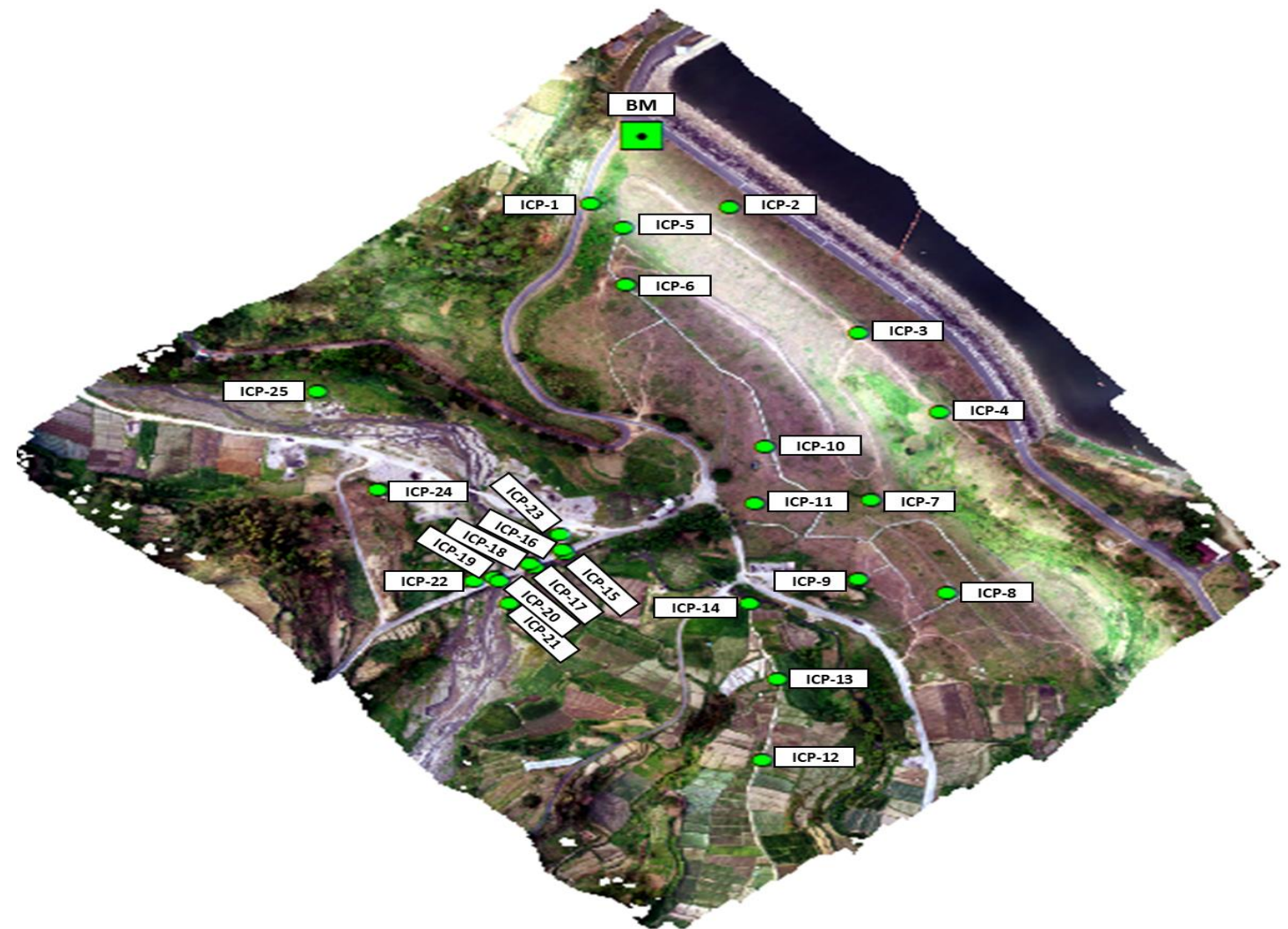

Gambar 3. Persebaran titik ICP

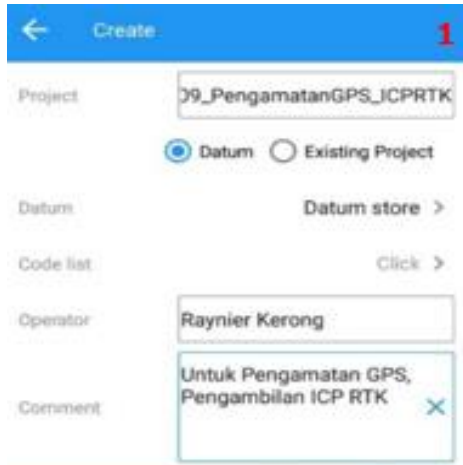

$\leftarrow$ Datum Store
Datum list
Indonesia/INDONESIA/DGN95 TM-3 zone
$49-2$
Indonesia/INDONESIA/DGN95 UTM zone 52N
Indonesia/INDONESIA/DGN95 UTM zone 49S
China/Beijing 1954
China/Xian 1980
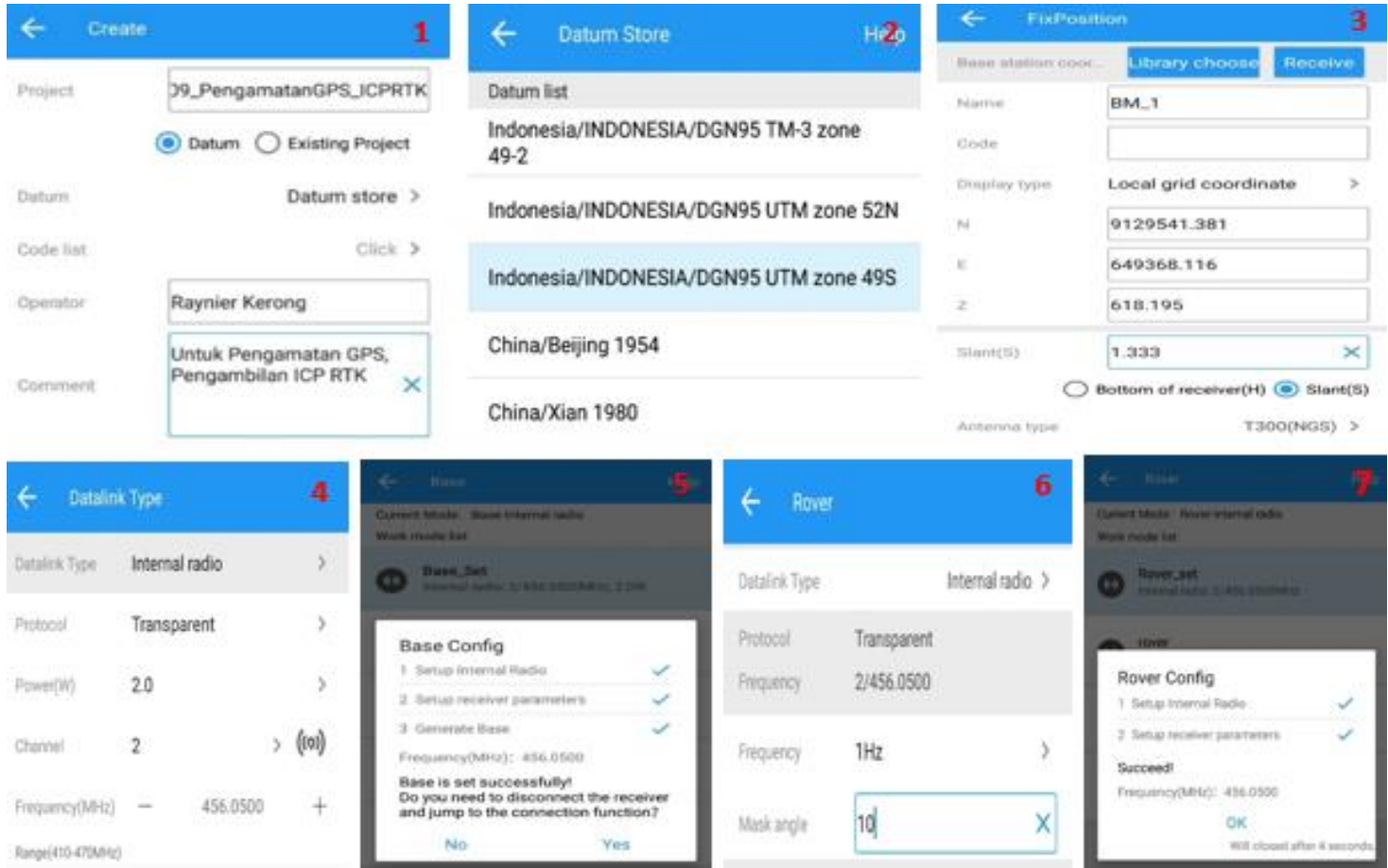

Gambar 4. Proses setting base dan rover untuk pengambilan data metode RTK

Penentuan jumlah persebaran ICP didasarkan pada standar ASPRS dan disesuaikan dengan luas area penelitian. Jumlah ICP yang digunakan dalam penelitian ini adalah 25 titik (ASPRS, 2015). Patok yang dijadikan sebagai titik ICP sama dengan GCP, yang di buat sendiri dari beton dan memanfaatkan patok ada di area penelitian. Persebaran 25 titik ICP tersaji pada Gambar 3. Pengambilan data ICP menggunakan GPS Comnav T300 metode Real Time Kinematic (RTK). Metode RTK menggunakan Network Transport of RTCM via Internet Protocol (NTRIP), dengan 


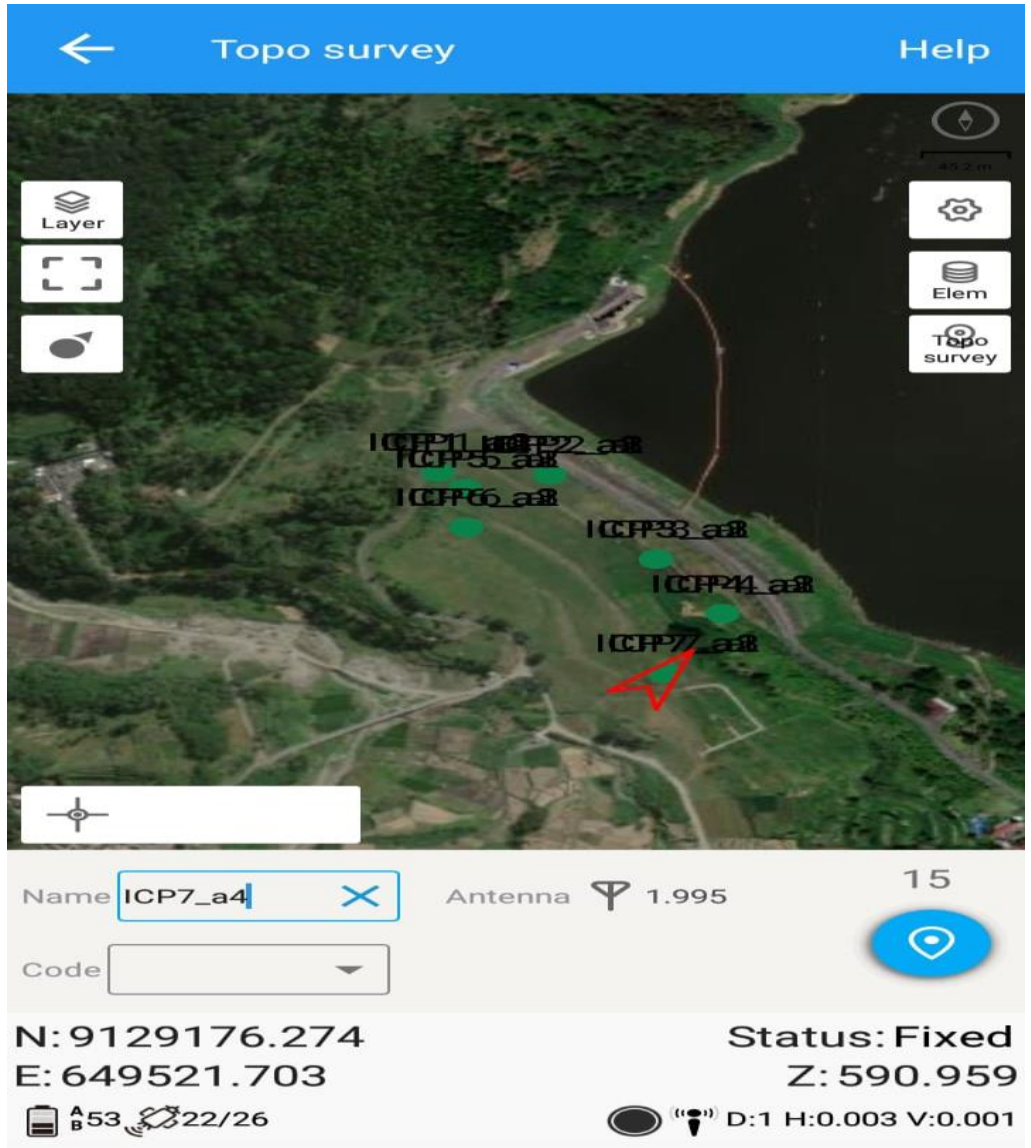

Gambar 6. Setting untuk pengambilan data ICP

waktu pengamatan 15 detik (Harfan et al., 2019). Adapun proses setting RTK yang dilakukan dapat dilihat pada Gambar 4. Pengambilan data dilakukan sebanyak 4 kali Fixed pada setiap titik/patok ICP seperti pada Gambar 6. Pengamatan ini menggunakan 2 receiver, dimana Base tetap pada titik BM dan Rover yang berpindah dari titik ICP 1, ICP 2 dan berurutan sampai ICP 25, sehingga menghasilkan 25 data titik koordinat.

\subsubsection{Persiapan dan Pengumpulan Data Spotheight}

Tahapan ini tujuan utamanya adalah memperoleh data koordinat Spotheight. Tahap persiapan yang dilakukan adalah pengecekan kelengkapan alat total station beserta instrument pendukung lainnya dan penentuan titik berdiri alat. Penempatan alat berada pada tempat yang bebas dan luas pandangan, sehingga dapat di maksimalkan dalam pengambilan data. Apabila persiapan sudah tepat, maka selanjutnya dilakukan pengambilan data detail ketinggian tanah (Spotheight) (Fauzan et al., 2021). Pengumpulan data tersebut menggunakan alat Total Station Topcon ES-65 SN: YL1492. Metode pengukurannya memanfaatkan titik-titik GCP dan ICP yang sudah diketahui koordinatnya sebagai Backsight (titik stasiun belakang) dan juga sebagai titik alat berdiri. Detail ketinggian tanah diperoleh dari bidikan ke prisma/reflektor yang digunakan sebagai titik pengukuran. Setiap titik detail diambil sebanyak 3 kali dan dilakukan pada 1454 titik detail ketinggian tanah yang tersebar di seluruh area penelitian. Pengukuran ini menghasilkan 1454 titik koordinat detail ketinggian tanah (spotheight).

\subsubsection{Persiapan dan Pengumpulan Data Foto Udara}

Tahapan ini tujuan utamanya adalah memperoleh data foto udara melalui survey lokasi, pemasangan premark, dan membuat rencana jalur terbang. Prosedur ini berdasarkan Peraturan BIG No.1 Tahun 2020, akan tetapi disesuaikan dengan area penelitian dan tujuan pengambilan data. Diantaranya menentukan Area of Interest (AOI), membuat jalur terbang sesuai dengan bentuk AOI dan topografinya, mendesain pertampalan ke muka (forward overlap) $\geq 60 \%$, mendesain pertampalan ke samping (side overlap) $\geq 30 \%$, mendesain nilai Ground Sampling Distance (GSD) 
dengan target GSD $<5 \mathrm{~cm}$, posisi base station harus berada pada daerah terbuka (BIG, 2020). Jika persiapan sudah selesai, selanjutnya melakukan pengambilan data Foto Udara menggunakan wahana UAV yaitu Drone Dji Phantom 4 Pro yang menghasilkan 1654 data foto.

\subsection{Pengolahan Data}

Sebelum dilakukan pengolahan data, hal penting dilakukan adalah kontrol kualitas data, meliputi: (1) kontrol kualitas data rinex pada hasil pengamatan GPS yaitu khususnya data GCP karena menggunakan metode rapit static, (2) mengetahui kualitas data ICP hasil pengamatan menggunakan metode RTK, dengan melakukan perhitungan ketelitian data yaitu standar deviasi rata-rata dari 25 titik ICP. Semakin kecil standar deviasinya maka semakin bagus juga datanya, (3) mengetahui kualitas data spotheight hasil pengukuran Total station metode Radial, dengan melakukan perhitungan ketelitian data yaitu standar deviasi rata-rata dari 1454 titik spotheight. Semakin kecil standar deviasinya maka semakin bagus juga datanya, (4) mengetahui kualitas data foto udara dari pemotretan menggunakan wahana UAV, dengan me-report kualitas data hasil pemotretannya menggunakan sebuah software fotogrametri, khususnya report hasil orthorektifikasi terhadap 4 titik GCP untuk mengetahui hasil akurasi terhadap sumbu x, y, dan z.

Pengolahan data dilakukan dengan menggunakan beberapa software, antara lain: (1) software fotogrametri untuk pengolahan data foto udara dan data GCP menjadi DSM dan Orthophoto, (2) PCI Geomatica 2014 dengan metode pengolahan semi-otomatis filtering digunakan untuk pengolahan data DSM menjadi DTM, (3) SAGA GIS 7.7.0 dengan metode pengolahan otomatis filtering digunakan untuk pengolahan data DSM menjadi DTM, (4) software pemetaan digunakan untuk pengolahan data spotheight menjadi DTM spotheight topografi, Uji ketelitian DSM terhadap data ICP, dan Validasi statistik DTM hasil dari 2 software berbeda terhadap data spotheight, (5) software pemetaan digunakan untuk uji validasi non-statistik (visual) DTM metode profil melintang dari 2 software berbeda terhadap DTM spotheight Topografi, (6) Microsoft Excel 2019 digunakan untuk perhitungan data spotheight. Perhitungan data ICP, perhitungan RMSE berdasarkan standar ASPRS (2015), perhitungan uji ketelitian DSM terhadap ICP, dan perhitungan validasi statistik DTM hasil dari 2 software berbeda terhadap data spotheight.

\subsection{Analisis Data}

Fokus utama penelitian ini adalah membandingkan 2 software yaitu; SAGA GIS dengan metode pengolahan otomatis filtering dan PCI Geomatica dengan metode pengolahan semi-otomatis filtering, untuk mengetahui DTM yang lebih presisi dan akurat hasil perbandingan 2 software tersebut. Validasi atau data pembanding yang digunakan adalah data detail ketinggian tanah (spotheight) hasil pengukuran secara terestris yang di anggap benar dan mewakili nilai ketinggian sebenarnya dilapangan.

Sebelum proses validasi DTM terhadap data spotheight, melakukan analisis ketelitian data DSM terhadap ICP. Hal tersebut dilakukan untuk mengatahui tingkat ketelitian DSM yang dijadikan bahan utama untuk menghasilkan DTM. Mengetahui ketelitian dari DSM, dilakukan perhitungan Root Mean Square Error (RMSE). RMSE adalah suatu Teknik peramalan yang digunakan untuk mengukur tingkat akurasi hasil prakiraan suatu model. RMSE merupakan nilai rata-rata dari jumlah kuadrat kesalahan. Selain itu, menyatakan ukuran besarnya kesalahan yang di hasilkan oleh suatu model prakiraan. Nilai RMSE dihitung menggunakan Persamaan 1, 2, dan 3 (Putra, 2016) :

$$
\begin{aligned}
& \text { RMSEx }=\sqrt{\frac{\sum(\mathrm{x} \text { data, } \mathrm{i}-\mathrm{x} \mathrm{cek}, \mathrm{i})^{2}}{\mathrm{n}}} \\
& \text { RMSEy }=\sqrt{\frac{\sum(\mathrm{y} \text { data, } \mathrm{i}-\mathrm{y} \mathrm{cek}, \mathrm{i})^{2}}{\mathrm{n}}} \\
& \text { RMSEz }=\sqrt{\frac{\sum(\mathrm{z} \text { data, } \mathrm{i}-\mathrm{z} \mathrm{cek}, \mathrm{i})^{2}}{\mathrm{n}}}
\end{aligned}
$$


Tabel 1. Standar akurasi horizontal untuk data geospasial

Akurasi Mutlak

\begin{tabular}{lllll}
\hline & \multicolumn{2}{l}{ Akurasi Mutlak } & & \\
\cline { 2 - 5 } $\begin{array}{l}\text { Kelas } \\
\begin{array}{l}\text { akurasi } \\
\text { horizontal }\end{array}\end{array}$ & $\begin{array}{l}\text { RMSEx dan } \\
\text { RMSEy }(\mathrm{cm})\end{array}$ & RMSEr $(\mathrm{cm})$ & $\begin{array}{l}\text { Akurasi horizontal pada tingkat } \\
\text { kepercayaan 95\% }(\mathrm{cm})\end{array}$ & $\begin{array}{l}\text { Ketidakcocokan } \\
\text { seamline citra } \\
\text { ortho mosaic }(\mathrm{cm})\end{array}$ \\
\hline $\mathrm{X}-\mathrm{cm}$ & $\leq \mathrm{X}$ & $\leq 1.414^{*} \mathrm{X}$ & $\leq 2.448^{*} \mathrm{X}$ & $\leq 2^{*} \mathrm{X}$ \\
\hline Sumber: ASPRS $(2015)$ & & &
\end{tabular}

Tabel 2. Akurasi horizontal/ contoh kualitas untuk data geospasial

\begin{tabular}{llllll}
\hline Skala peta & $\begin{array}{l}\text { Perkiraan } \\
\text { sumber gambar } \\
\text { GSD }\end{array}$ & $\begin{array}{l}\text { Kelas akurasi } \\
\text { data horizontal }\end{array}$ & $\begin{array}{l}\text { RMSEx } \\
\text { atau } \\
\text { RMSEy } \\
(\mathrm{cm})\end{array}$ & $\begin{array}{l}\text { RMSEr } \\
(\mathrm{cm})\end{array}$ & $\begin{array}{l}\text { Akurasi horizontal } \\
\text { pada tingkat } \\
\text { kepercayaan } 95 \% \\
(\mathrm{~cm})\end{array}$ \\
\hline \multirow{3}{*}{$1: 100$} & \multirow{2}{*}{$1-2 \mathrm{~cm}$} & I & 1.3 & 1.8 & 3.1 \\
& & II & 2.5 & 3.5 & 6.1 \\
$1: 200$ & III & 3.8 & 5.3 & 9.2 \\
& $2-3 \mathrm{~cm}$ & I & 2.5 & 3.5 & 6.1 \\
& & II & 5.0 & 7.1 & 12.2 \\
& III & 7.5 & 10.6 & 18.4 \\
\hline
\end{tabular}

Sumber: ASPRS (2015)

Tabel 3. Standar akurasi vertikal untuk data elevasi digital

\begin{tabular}{|c|c|c|c|c|c|c|}
\hline \multirow[b]{2}{*}{$\begin{array}{l}\text { Kelas } \\
\text { akurasi } \\
\text { vertikal }\end{array}$} & \multicolumn{3}{|c|}{ Akurasi mutlak } & \multicolumn{3}{|c|}{ Akurasi relatif (jika ada) } \\
\hline & $\begin{array}{l}\text { RMSez } \\
\text { non- } \\
\text { vegetasi } \\
(\mathrm{cm})\end{array}$ & $\begin{array}{l}\text { NVA } \\
\text { pada } \\
\text { tingkat } \\
\text { kepercaya } \\
\text { an 95\% } \\
\text { (cm) }\end{array}$ & $\begin{array}{l}\text { VVA pada } \\
\text { tingkat } \\
\text { kepercaya } \\
\text { an } 95 \% \\
(\mathrm{~cm})\end{array}$ & $\begin{array}{l}\text { Di dalam petak } \\
\text { pengulangan } \\
\text { permukaan } \\
\text { yang keras } \\
\text { (perbedaan } \\
\text { maks) }(\mathrm{cm})\end{array}$ & $\begin{array}{l}\text { Petak-ke-petak } \\
\text { medan non- } \\
\text { vegetasi } \\
(\text { RMSDz) }(\mathrm{cm})\end{array}$ & $\begin{array}{l}\text { Petak-ke-petak } \\
\text { medan non- } \\
\text { vegetasi } \\
\text { (perbedaan } \\
\text { maks) }(\mathrm{cm})\end{array}$ \\
\hline $\mathrm{X}-\mathrm{cm}$ & $\leq \mathrm{X}$ & $\leq 1.96 * X$ & $\leq 3.00 * X$ & $\leq 0.60^{*} \mathrm{X}$ & $\leq 0.80 * X$ & $\leq 1.60 * X$ \\
\hline
\end{tabular}

Sumber: ASPRS (2015)

Tabel 4. Akurasi vertikal / contoh kualitas untuk data elevasi digital

\begin{tabular}{|c|c|c|c|c|}
\hline $\begin{array}{l}\text { Kelas } \\
\text { akurasi } \\
\text { data } \\
\text { vertikal }\end{array}$ & $\begin{array}{l}\text { RMSEz di } \\
\text { medan non- } \\
\text { vegetasi }(\mathrm{cm})\end{array}$ & $\begin{array}{l}\text { Akurasi vertikal } \\
\text { non-vegetasi } \\
\text { pada tingkat } \\
\text { kepercayaan } 95 \% \\
\text { (cm) }\end{array}$ & $\begin{array}{l}\text { Akurasi vertikal } \\
\text { bervegetasi (VVA) pada } \\
\text { tingkat kepercayaan } 95 \% \\
(\mathrm{~cm})\end{array}$ & $\begin{array}{l}\text { Petak akurasi relatif di } \\
\text { medan yang non- } \\
\text { vegetasi } \\
(\mathrm{RMSDz} / \text { perbedaan } \\
\text { maks) }(\mathrm{cm})\end{array}$ \\
\hline I & 1.0 & 2.0 & 2,9 & $0.8 / 1.6$ \\
\hline II & 2,5 & 4.9 & 7.4 & $2.0 / 4.0$ \\
\hline III & 5.0 & 9.8 & 14,7 & $4.0 / 8.0$ \\
\hline IV & 10,0 & 19,6 & 29,4 & $8.0 / 16.0$ \\
\hline V & 12,5 & 24,5 & 36,8 & $10.0 / 20.0$ \\
\hline VI & 20,0 & 39.2 & 58,8 & $16.0 / 32.0$ \\
\hline VII & 33.3 & 65.3 & 98,0 & $26.7 / 53.3$ \\
\hline
\end{tabular}

Sumber: ASPRS (2015)

dimana: RMSEx adalah Nilai root mean square error $\mathrm{x}$; RMSEy adalah Nilai root mean square error y; RMSEz adalah Nilai root mean square error $\mathrm{z}$; $\mathrm{x}$ data $\mathrm{i}$, y data $\mathrm{i}$, dan $\mathrm{z}$ data I adalah Koordinat posisi titik ke-1 data set; $x$ cek i, y cek i, dan z cek I adalah Koordinat posisi titik ke-1 data titik cek; $n$ adalah Jumlah titik cek yang diuji; I adalah Bilangan bulat dari 1 sampai $n$. Nilai RMSE untuk komponen horizontal dihitung menggunakan Persamaan (4) dan (5):

RMSEr $=\sqrt{\frac{\sum(\mathrm{x} \text { data, } \mathrm{i}-\mathrm{x} \mathrm{cek}, \mathrm{i})^{2}+(\mathrm{y} \text { data, } \mathrm{i}-\mathrm{y} \mathrm{cek}, \mathrm{i})^{2}}{\mathrm{n}}}$ 
$\operatorname{RMSEr}=\sqrt{(\mathrm{RMSEx})^{2}+(\mathrm{RMSEy})^{2}}$

RMSE untuk komponen horizontal dihitung menggunakan Persamaan 6 dan komponen vertikal menggunakan Persamaan 7, pada tingkat kepercayaan 95\%.

RMSEr $=1.7308 *$ RMSEr
RMSEz $=1.9600 *$ RMSEz

Hasil perhitungan RMSE pada tingkat kepercayaan 95\% disesuaikan dengan Akurasi horizontal/ contoh kualitas untuk data geospasial yang tersaji pada Tabel 2, Akurasi vertikal/ contoh kualitas untuk data elevasi digital tersaji pada Tabel 4, sesuai dengan standar ASPRS untuk di analisis kelas akurasinya serta skala pada peta (ASPRS, 2015). Perhitungan RMSE ini selain digunakan untuk pengujian ketelitian DSM terhadap ICP. Selain itu, digunakan untuk Uji Validasi dan Analisis DTM hasil pengolahan software SAGA GIS (metode otomatis filtering) dengan PCI Geomatica (metode semi-otomatis filtering) terhadap data Spotheight. DTM yang memiliki RMSE paling kecil, dalam hal ini yang difokuskan adalah ketelitian vertikalnya (RMSEz), adalah DTM yang diasumsikan lebih presisi dan akurat.

\section{HASIL DAN PEMBAHASAN}

\subsection{Hasil Pengolahan Data GCP dan ICP}

Data mentah terlebih dahulu diolah pada software pengolahan data GPS, sehingga data hasil pengukuran lebih akurat dan sesuai dengan posisi sebenarnya dilapangan. Adapun hasil kualitas data rinex dari pengamatan 4 GCP tersaji seperti Tabel 5 dan multipath for GNSS signal untuk GCP tersaji pada Gambar 7. Hasil pengolahan data GCP ditunjukan pada Tabel 6, desain pengikatan titik GCP terhadap BM tersaji pada Gambar 8. Pengambilan data menggunakan GPS juga menghasilkan 25 data titik koordinat ICP dengan metode RTK. Data koordinat ICP tersebut kemudian dihitung rata-rata dan standar deviasinya dengan hasil seperti tersaji pada Tabel 7, desain pengikatan titik ICP terhadap BM seperti tersaji pada Gambar 8.

\subsection{Hasil Pengolahan Data Spotheight}

Pengolahan data spotheight menggunakan 2 software yaitu software pengolahan data total station untuk mengecek data terekam atau tidaknya saat pengukuran dan software Microsoft Excel untuk menghitung datanya. Pengolahan ini menghasilkan data koordinat spotheight seperti tersaji pada Tabel 8.

\subsection{Hasil Pengolahan Data Foto Udara}

Pengolahan foto udara dilakukan dengan menggunakan software fotogrametri, proses tersebut menggunakan data foto sebanyak 1654 foto, 1 titik koordinat BM, dan 4 titik koordinat GCP yang diperoleh dari hasil pengukuran GPS. Secara garis besar, proses ini dinamakan orthorektifikasi dengan hasil reportnya tersaji pada Gambar 9. Adapun hasil pengolahan data foto udara tersebut

Tabel 5. Kualitas data rinex dari pengamatan 4 GCP

\begin{tabular}{|c|c|c|c|c|c|c|c|c|}
\hline No & $\begin{array}{l}\text { Baseline } \\
\text { pengamatan }\end{array}$ & Diproses & $\begin{array}{l}\text { Jenis } \\
\text { solusi }\end{array}$ & $\begin{array}{l}\text { Frekuensi } \\
\text { yang } \\
\text { digunakan }\end{array}$ & $\begin{array}{l}\text { Presisi } \\
\text { Horizontal }\end{array}$ & $\begin{array}{l}\text { Presisi } \\
\text { Vertikal }\end{array}$ & RMS & $\begin{array}{l}\text { Durasi } \\
\text { pemrosesan }\end{array}$ \\
\hline 1 & $\begin{array}{l}\mathrm{BM}_{1} . . \mathrm{GCP} \\
1 \text { (B1) }\end{array}$ & $\begin{array}{l}\text { Invalid } \\
\text { leap } \\
\text { seconds }\end{array}$ & Fixed & $\begin{array}{l}\text { Dual } \\
\text { Frequency } \\
(\mathrm{L} 1, \mathrm{~L} 2)\end{array}$ & $0,005 \mathrm{~m}$ & $0,008 \mathrm{~m}$ & $\begin{array}{l}0,015 \\
\mathrm{~m}\end{array}$ & $0: 30: 40$ \\
\hline 2 & $\begin{array}{l}\mathrm{BM}_{2} . . \mathrm{GCP} \\
2(\mathrm{~B} 2)\end{array}$ & $\begin{array}{l}\text { Invalid } \\
\text { leap } \\
\text { seconds }\end{array}$ & Fixed & $\begin{array}{l}\text { Dual } \\
\text { Frequency } \\
(\mathrm{L} 1, \mathrm{~L} 2)\end{array}$ & $0,004 \mathrm{~m}$ & $0,005 \mathrm{~m}$ & $\begin{array}{l}0,010 \\
\mathrm{~m}\end{array}$ & $0: 30: 00$ \\
\hline 3 & $\begin{array}{l}\mathrm{BM}_{3} . . \mathrm{GCP} \\
3(\mathrm{~B} 1)\end{array}$ & $\begin{array}{l}\text { Invalid } \\
\text { leap } \\
\text { seconds }\end{array}$ & Fixed & $\begin{array}{l}\text { Dual } \\
\text { Frequency } \\
(\mathrm{L} 1, \mathrm{~L} 2)\end{array}$ & $0,003 \mathrm{~m}$ & $0,006 \mathrm{~m}$ & $\begin{array}{l}0,008 \\
\mathrm{~m}\end{array}$ & $0: 29: 50$ \\
\hline 4 & $\begin{array}{l}\mathrm{BM}_{4} . . \mathrm{GCP} \\
4(\mathrm{~B} 2)\end{array}$ & $\begin{array}{l}\text { Invalid } \\
\text { leap } \\
\text { seconds }\end{array}$ & Fixed & $\begin{array}{l}\text { Dual } \\
\text { Frequency } \\
(\mathrm{L} 1, \mathrm{~L} 2)\end{array}$ & $0,004 \mathrm{~m}$ & $0,006 \mathrm{~m}$ & $\begin{array}{l}0,012 \\
\mathrm{~m}\end{array}$ & $0: 32: 30$ \\
\hline
\end{tabular}




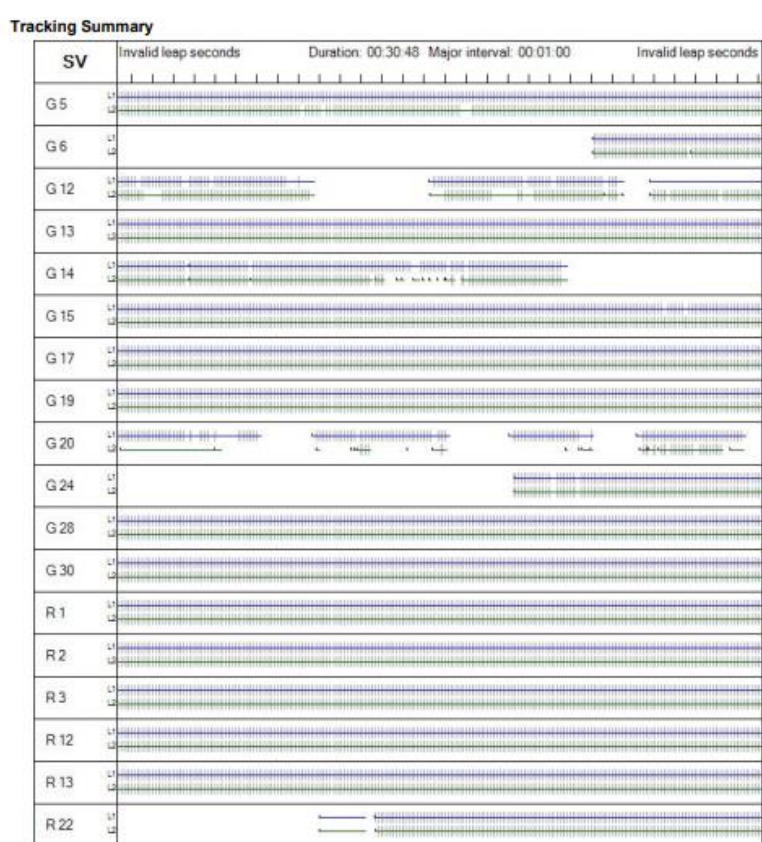

(a)

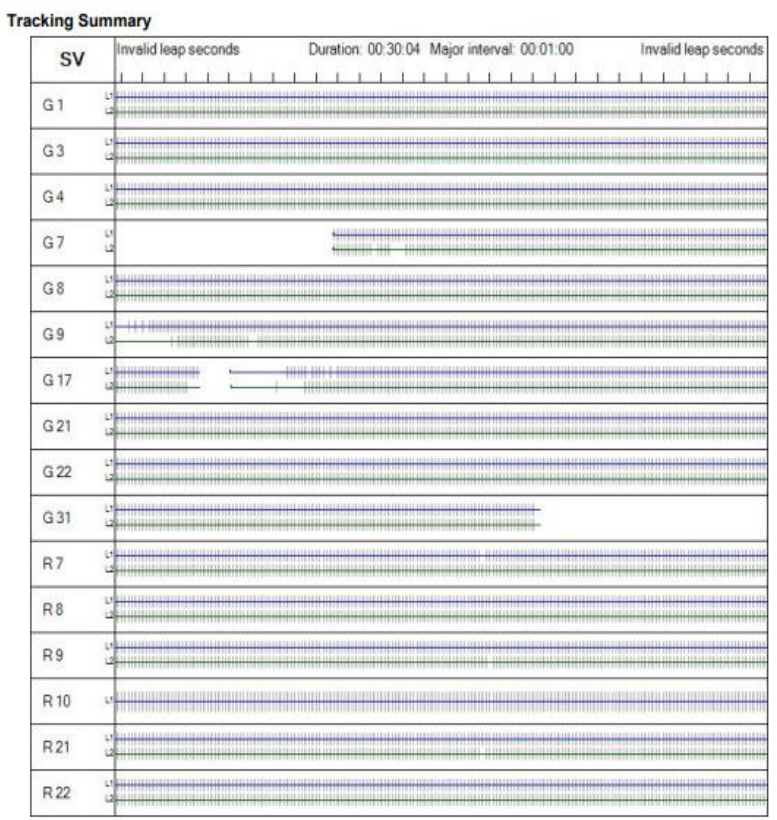

(c)

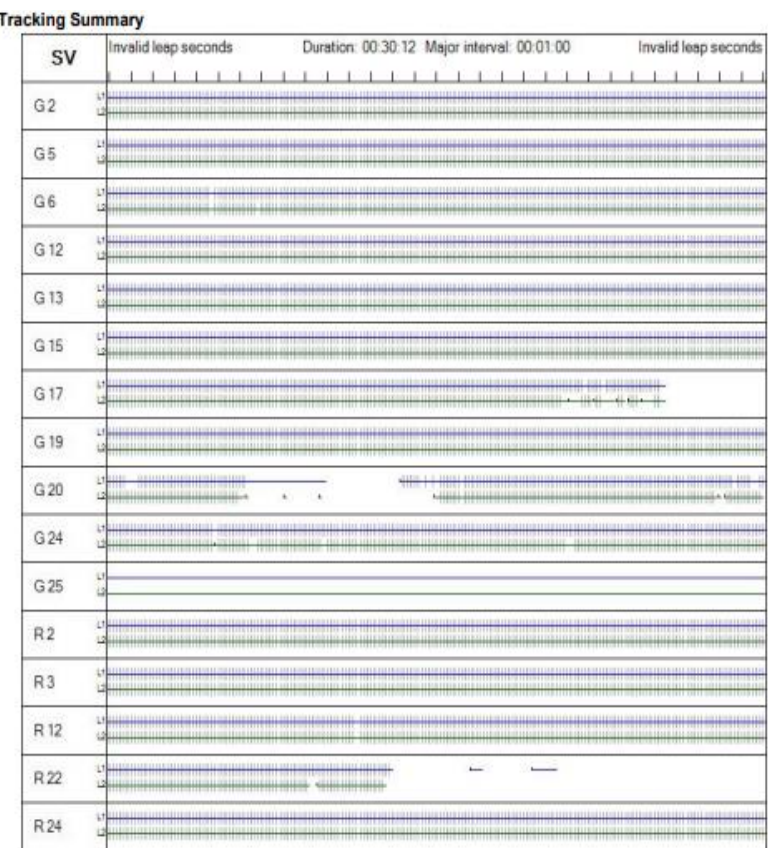

(b)

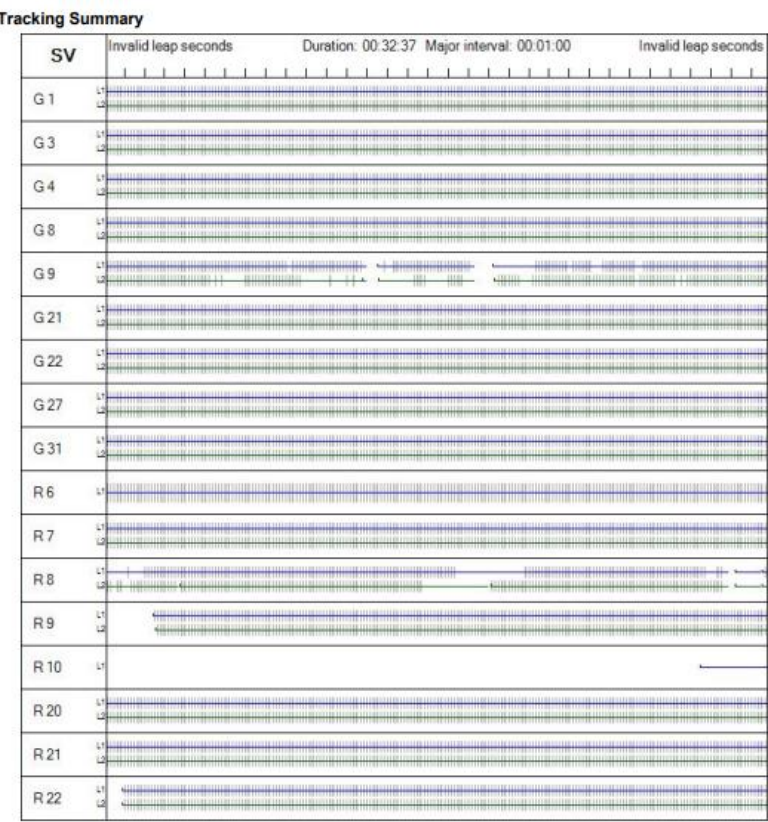

(d)

Gambar 7. Multipath untuk GNSS signal data; (a) GCP 1, (b) GCP 4, (c) GCP 2, (d) GCP 3

berupa DSM yang memuat informasi berupa data ketinggian Vegetasi dan Non Vegetasi tersaji pada Gambar 10 dan orthophoto yang menggambarkan posisi dan objek apa saja yang ada pada daerah penelitian seperti tersaji pada Gambar 11. Selanjutnya setelah data DSM dan Orthophoto diperoleh maka dilakukan analisis ketelitian yang meliputi analisis ketelitian Horizontal (Ketelitian Orthophoto) dan ketelitian Vertikal (Ketelitian DSM), analisis ini dilakukan dengan menggunakan perhitungan RMSE Horizontal dan Vertikal, untuk mengetahui besarnya nilai ketelitian Horizontal dan Vertikal berdasarkan pada standar ASPRS (2015).

\subsubsection{Hasil Analisis Ketelitian Horizontal (Ketelitian Orthophoto)}

Ketelitian Horizontal dihasilkan dari besarnya kesalahan atau perbedaan posisi objek di peta (Orthophoto) dengan posisi sebenarnya (ICP). Proses analisis ini dilakukan dengan cara menghitung selisih nilai koordinat $\mathrm{x}$ dan $\mathrm{y}$ dari 25 titik ICP hasil dari pengukuran GPS dengan nilai koordinat $\mathrm{x}$ dan y dari Orthophoto yang sudah didigitasi menggunakan software pemetaan. Digitasi yang 
Tabel 6. Hasil pengolahan data GCP

\begin{tabular}{lllllll}
\hline Point ID & $\mathrm{X}(\mathrm{m})$ & $\mathrm{Y}(\mathrm{m})$ & $\mathrm{Z}(\mathrm{m})$ & $\sigma \mathrm{X}(\mathrm{m})$ & $\sigma \mathrm{Y}(\mathrm{m})$ & $\sigma \mathrm{Z}(\mathrm{m})$ \\
\hline BM & 649368.116 & 9129541.381 & 618.195 & & & \\
GCP_1 & 649700.146 & 9129097.718 & 625.985 & 0.002 & 0.002 & 0.004 \\
GCP_2 & 649322.02 & 9129126.314 & 570.116 & 0.001 & 0.001 & 0.003 \\
GCP_3 & 649379.33 & 9128871.361 & 590.478 & 0.002 & 0.001 & 0.003 \\
GCP_4 & 649114.958 & 9129238.722 & 560.617 & 0.001 & 0.001 & 0.003 \\
\hline Total $(\mathrm{m})$ & & & & 0.006 & 0.005 & 0.013 \\
\hline Akurasi $\sigma(\mathrm{X}, \mathrm{Y}, \mathrm{Z})(\mathrm{m})$ & & & 0.008 & & \\
\hline
\end{tabular}

Tabel 7. Hasil pengolahan data ICP

\begin{tabular}{lllllll}
\hline Point ID & $\mathrm{X}(\mathrm{m})$ & $\mathrm{Y}(\mathrm{m})$ & $\mathrm{Z}(\mathrm{m})$ & $\sigma \mathrm{X}(\mathrm{m})$ & $\sigma \mathrm{Y}(\mathrm{m})$ & $\sigma \mathrm{Z}(\mathrm{m})$ \\
\hline ICP_1 & 649332.1318 & 9129473.037 & 609.2274 & 0.0061 & 0.0059 & 0.0028 \\
ICP_2 & 649425.8483 & 9129469.427 & 611.30125 & 0.003 & 0.0111 & 0.0047 \\
ICP_3 & 649513.5624 & 9129344.058 & 603.9826 & 0.0104 & 0.0168 & 0.0048 \\
ICP_4 & 649568.8388 & 9129263.589 & 614.416 & 0.0072 & 0.0105 & 0.0055 \\
$\ldots$. & $\ldots$ & $\ldots$. & $\ldots$ & $\ldots \ldots$ & $\ldots$. & $\ldots$. \\
ICP_25 & 649145.7498 & 9129284.368 & 559.589 & 0.0122 & 0.0221 & 0.044 \\
\hline Total $(\mathrm{m})$ & & & & 0.0095 & 0.0117 & 0.0053 \\
\hline \multicolumn{2}{l}{ Akurasi $\sigma(\mathrm{X}, \mathrm{Y}, \mathrm{Z})(\mathrm{m})$} & & & 0.009 & & \\
\hline
\end{tabular}
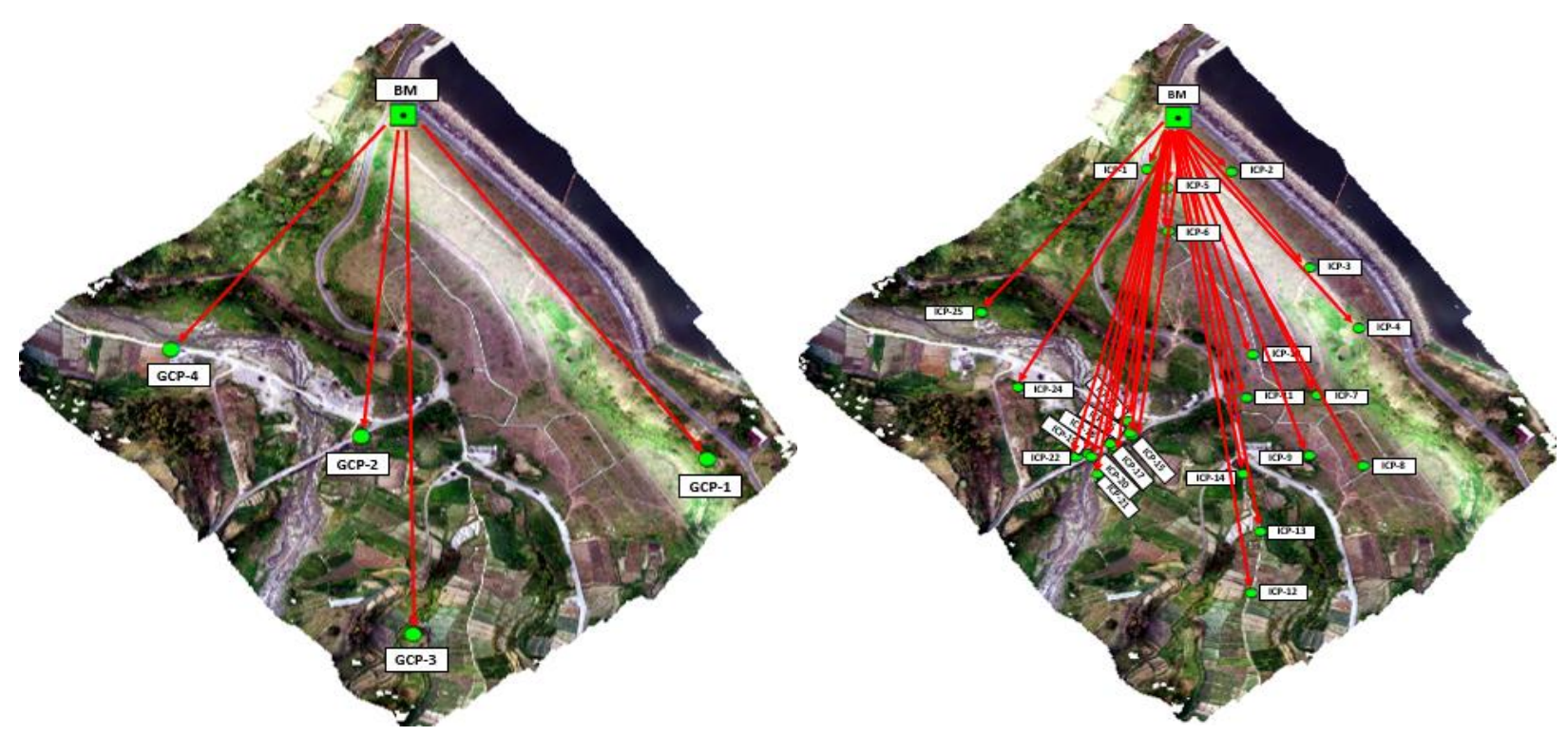

Gambar 8. Persebaran titik GCP (kiri) dan titik ICP (kanan), serta desain pengikatan terhadap BM

dimaksud adalah mendigitasi 25 patok/titik ICP yang terlihat pada orthophoto. Hasil perhitungan ini tersaji pada Tabel 9. Berdasarkan hasil perhitungan ketelitian horizontal, nilai NSSDA Horizontal Accuracy 95\% confidence Level adalah $0.20589 \mathrm{~m}(20.589 \mathrm{~cm})$. Ini berarti bahwa ketelitian Horizontal dengan tingkat kepercayaan 95\% menunjukan kesesuaian dengan standar ASPRS 2015 yang dapat dilihat pada Tabel 2, yaitu pada ketelitian skala peta 1:200.

\subsubsection{Hasil Analisis Ketelitian Vertikal (Ketelitian DSM)}

Ketelitian Vertikal dihasilkan dari besarnya nilai kesalahan atau perbedaan nilai ketinggian atau elevasi objek dipeta (DSM) dengan nilai ketinggian sebenarnya (ICP). Proses analisis ini dilakukan dengan menghitung selisih elevasi atau nilai koordinat $\mathrm{z}$ dari 25 titik ICP hasil dari pengukuran GPS, dengan elevasi atau nilai koordinat $\mathrm{z}$ dari DSM yang sudah didigitasi menggunakan software pemetaan. Digitasi yang dimaksud adalah mendigitasi 25 patok/titik ICP yang terlihat pada Orthophoto yang dioverlay dengan DSM, hasil perhitungan ini tersaji pada Tabel 10. Berdasarkan hasil perhitungan ketelitian vertikal, nilai NSSDA Vertical Accuracy pada tingkat kepercayaan 95\% 
Tabel 8. Hasil pengolahan data spotheight

\begin{tabular}{llllllll}
\hline No & Point ID & $\mathrm{X}(\mathrm{m})$ & $\mathrm{Y}(\mathrm{m})$ & $\mathrm{Z}(\mathrm{m})$ & $\sigma \mathrm{X}(\mathrm{m})$ & $\sigma \mathrm{Y}(\mathrm{m})$ & $\sigma \mathrm{Z}(\mathrm{m})$ \\
\hline 1 & DTL & 649316.5238 & 9129450.32 & 606.1441294 & 0.0012 & 0.0016 & 0.0002 \\
2 & DTL & 649313.3882 & 9129451.378 & 608.4272534 & 0.0009 & 0.0015 & 0.0001 \\
3 & DTL & 649309.7122 & 9129452.318 & 612.5202772 & 0.0015 & 0.0028 & 0.0002 \\
4 & DTL & 649323.4058 & 9129476.15 & 608.582518 & 0.0029 & 0.0042 & 0.0006 \\
5 & DTL & 649319.7031 & 9129476.891 & 611.7284916 & 0.003 & 0.004 & 0.0004 \\
$\ldots$ & $\ldots$ & $\ldots$ & $\ldots$ & $\ldots$ & $\ldots$ & $\ldots$ & $\ldots$ \\
1454 & DTL & 649307.4175 & 9129279.938 & 610.0034244 & 0.0005 & 0.0105 & 0.0009 \\
\hline \multicolumn{2}{l}{ Total $(\mathrm{m})$} & & & 0.0031 & 0.004 & 0.0016 \\
\hline \multicolumn{2}{l}{ Akurasi $\sigma(\mathrm{X}, \mathrm{Y}, \mathrm{Z})(\mathrm{m})$} & & 0.003 & & \\
\hline
\end{tabular}

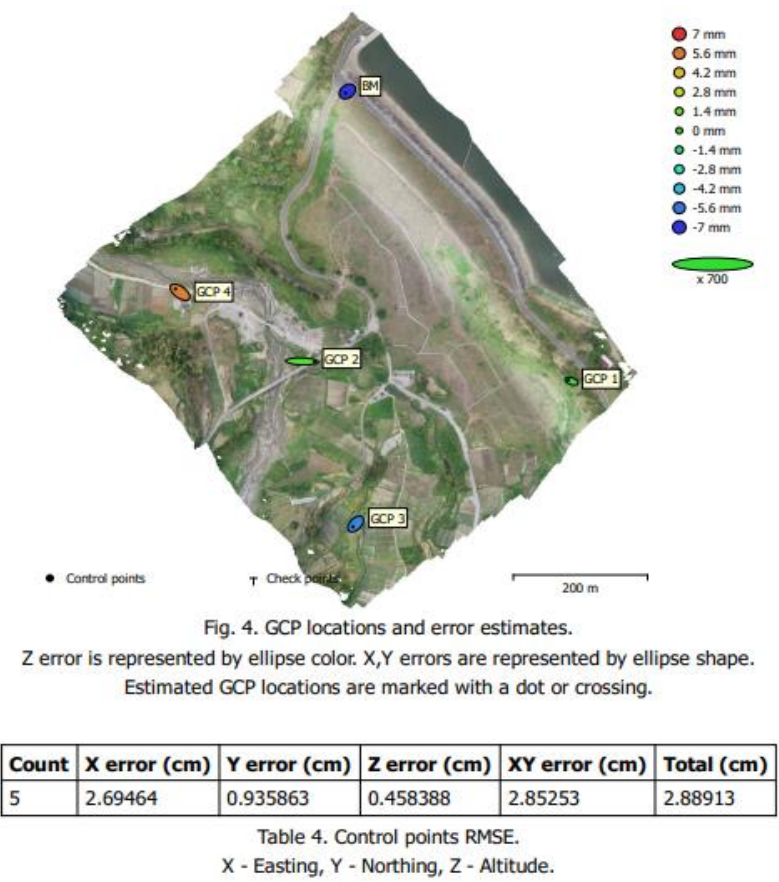

\begin{tabular}{|l|l|l|l|l|l|}
\hline Label & X error $(\mathbf{c m})$ & Y error (cm) & Z error (cm) & Total (cm) & Image (pix) \\
\hline BM & -0.799999 & -0.673504 & -0.689078 & 1.25237 & $0.301(38)$ \\
\hline GCP 1 & -1.38461 & 0.450365 & -0.0418475 & 1.45661 & $0.311(22)$ \\
\hline GCP 2 & 5.35429 & -0.145025 & 0.0689821 & 5.3567 & $0.441(74)$ \\
\hline GCP 3 & -1.15545 & -1.24385 & -0.525648 & 1.77723 & $0.379(43)$ \\
\hline GCP 4 & -1.93517 & 1.46784 & 0.54125 & 2.48845 & $0.439(42)$ \\
\hline Total & $\mathbf{2 . 6 9 4 6 4}$ & 0.935863 & $\mathbf{0 . 4 5 8 3 8 8}$ & $\mathbf{2 . 8 8 9 1 3}$ & $\mathbf{0 . 3 9 5}$ \\
\hline \multicolumn{5}{|c|}{ Table 5. Control points. } \\
\hline \multicolumn{5}{c}{ X-Easting, Y- Northing, Z-Altitude. }
\end{tabular}

Gambar 9. Hasil orthorektifikasi terhadap data BM dan 4 GCP

adalah $0.65227 \mathrm{~m}(65.227 \mathrm{~cm})$. Ini berarti bahwa ketelitian Vertikal dengan tingkat kepercayaan 95\% menunjukan kesesuaian dengan standar ASPRS (2015) yang dapat dilihat pada Tabel 4, yaitu pada Kelas akurasi data vertikal VII.

\subsection{Hasil Pengolahan Data DSM dan Data Spotheight Menjadi DTM}

Hasil DSM dari pengolahan software fotogrametri sebelumnya masih mengandung unsur vegetasi (pohon, bangunan, jalan, dll), sehingga perlu dilakukan filtering atau penapisan. Filtering yang dimaksud yaitu, menghilangkan unsur vegetasi untuk menghasilkan DTM yang hanya mengandung unsur Non Vegetasi (permukaan tanah/ground) tanpa ada unsur vegetasi di atasnya. Pengolahan data DSM dilakukan menggunakan software SAGA GIS dengan metode otomatis filtering dengan hasil DTM tersaji pada Gambar 12, dan software PCI Geomatica dengan metode otomatis-manual filtering dengan hasil DTM tersaji pada Gambar 13. Selanjutnya dilakukan pengolahan data ketinggian tanah (spotheight) dengan jumlah 1454 titik koordinat hasil pengukuran menggunakan total station, menggunakan software pemetaan. Hasil pengolahan ini menghasilkan DTM spotheight topografi tersaji pada Gambar 14.

\subsection{Hasil Uji Validasi DTM Foto Udara Terhadap Data Spotheight}

Uji validasi dilakukan untuk mengetahui seberapa besar selisih elevasi DTM foto udara dengan data Spotheight hasil pengukuran menggunakan total station. Uji validasi dalam penelitian ini dibedakan atas 2 yaitu uji validasi statistik dan non-statistik (visual). 


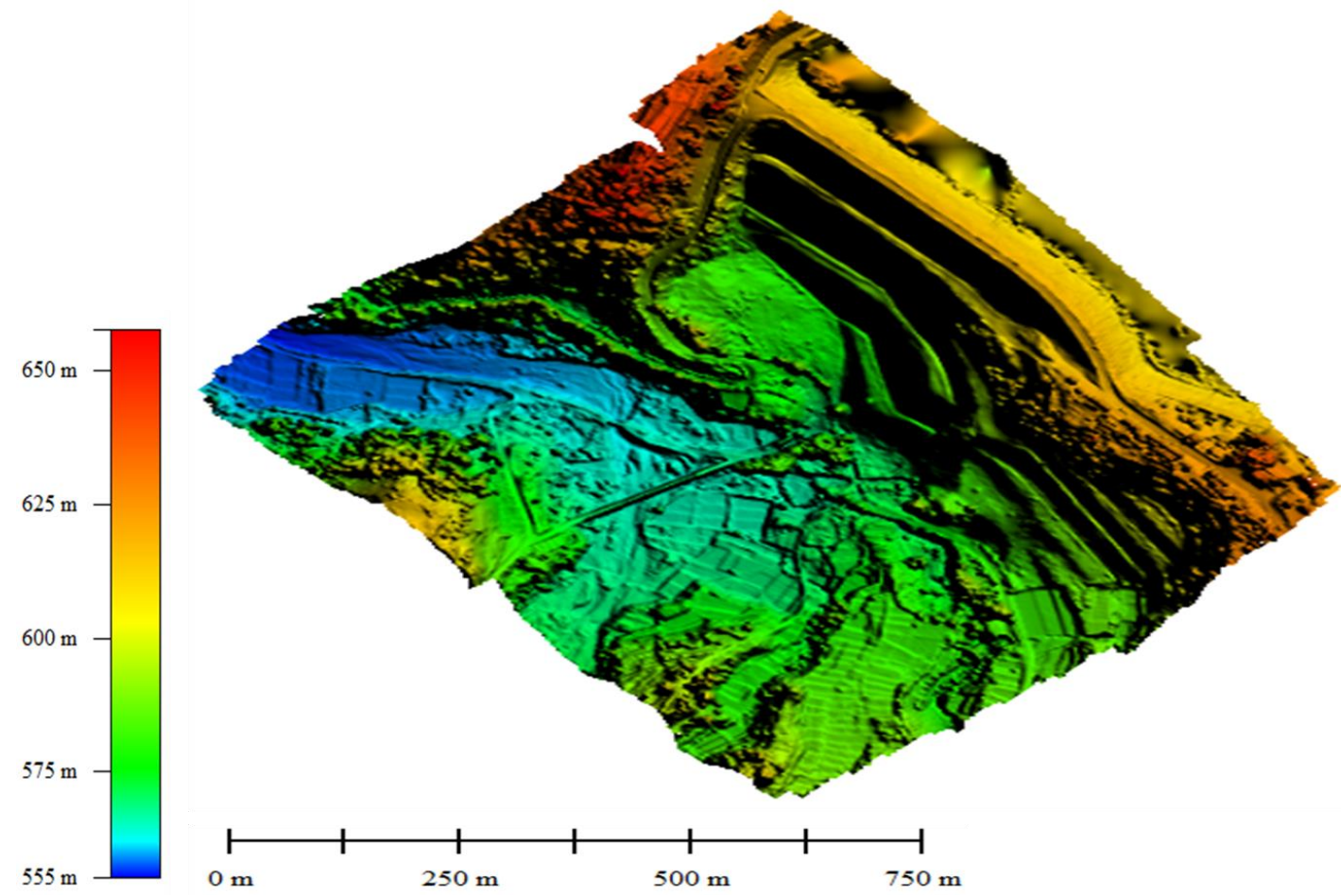

Gambar 10. Hasil DSM

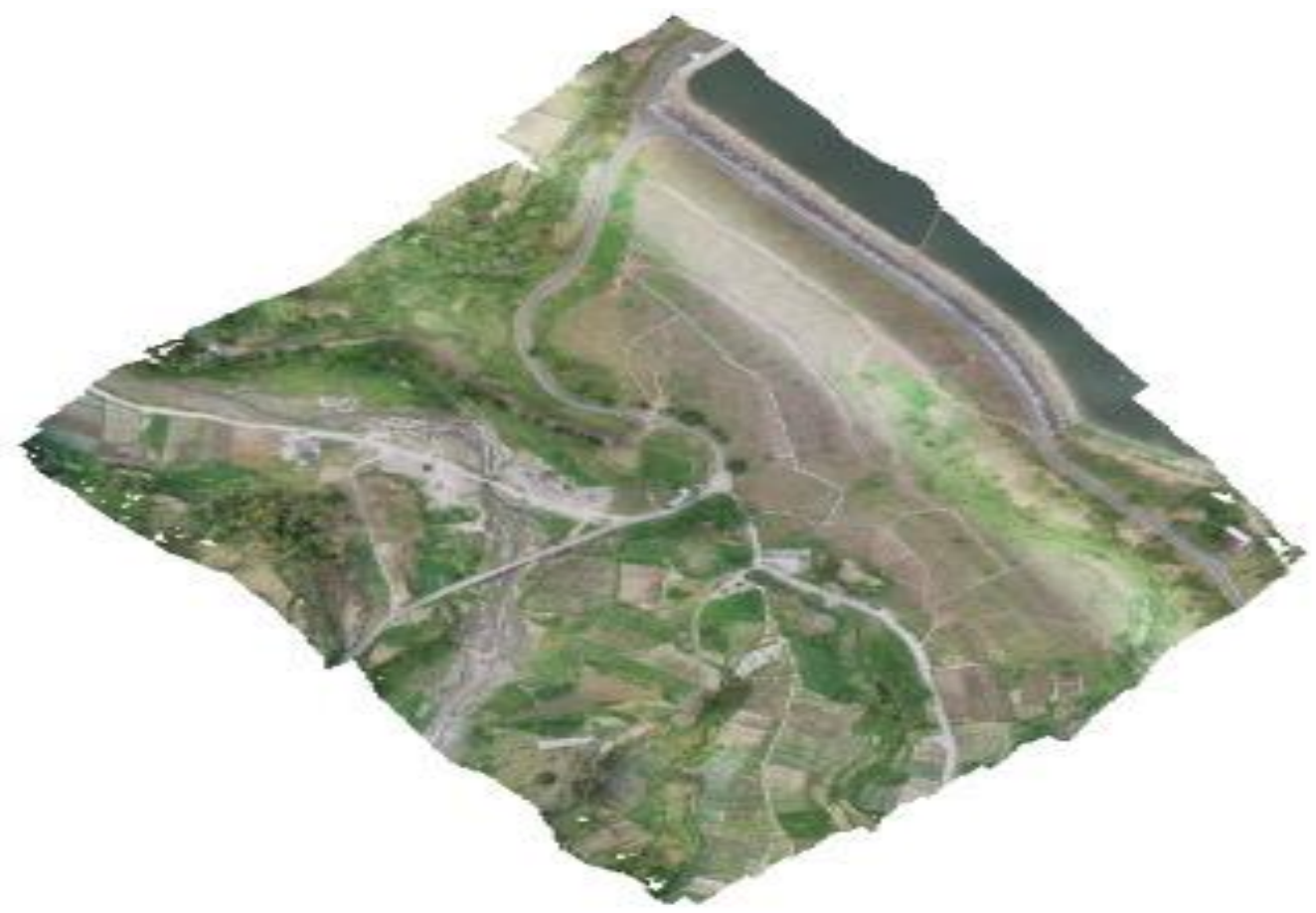

Gambar 11. Hasil Orthophoto

\subsubsection{Uji Validasi Statistik}

Uji validasi statistik dilakukan dengan cara menghitung selisih nilai elevasi dan nilai RMSEz dari 1454 titik referensi spotheight hasil dari pengukuran total station dengan DTM hasil pengolahan software SAGA GIS metode otomatis filtering dan software PCI Geomatica metode semi-otomatis filtering. DTM di digitasi menggunakan sebuah software pemetaan. Digitasi yang dimaksud adalah mendigitasi 1454 titik spotheight yang terlihat pada Orthophoto dan dioverlay dengan DTM hasil pengolahan software SAGA GIS metode otomatis filtering dan software PCI Geomatica metode semi-otomatis filtering. 
Tabel 9. Hasil perhitungan RMSE horizontal

\begin{tabular}{|c|c|c|c|c|c|c|}
\hline \multirow{2}{*}{$\begin{array}{l}\text { Point } \\
\text { ID }\end{array}$} & \multicolumn{2}{|c|}{ Koordinat orthophoto (m) } & \multicolumn{2}{|c|}{ Koordinat ICP (m) } & \multicolumn{2}{|c|}{ Residual errors $(\mathrm{m})$} \\
\hline & $\mathrm{x}$ & $\mathrm{y}$ & $\mathrm{X}$ & y & $\Delta \mathrm{x}^{2}$ & $\Delta \mathrm{y}^{2}$ \\
\hline$\overline{\mathrm{ICP} \_1}$ & 649332.0864 & 9129473.112 & 649332.1318 & 9129473.037 & 0.002060161 & 0.00567913 \\
\hline ICP_2 & 649425.8699 & 9129469.595 & 649425.8483 & 9129469.427 & 0.000467641 & 0.028106523 \\
\hline ICP_3 & 649513.5964 & 9129343.94 & 649513.5624 & 9129344.058 & 0.001153961 & 0.013978333 \\
\hline ICP_4 & 649568.8216 & 9129263.561 & 649568.8388 & 9129263.589 & 0.000294569 & 0.000774509 \\
\hline ICP_5 & 649354.5997 & 9129449.077 & 649354.61 & 9129448.851 & 0.000106936 & 0.050981124 \\
\hline & & & & & & \\
\hline ICP_25 & 649145.7442 & 9129284.504 & 649145.7498 & 9129284.368 & $3.12146 \mathrm{E}-05$ & 0.018580416 \\
\hline \multicolumn{5}{|c|}{ Number check point } & 25 & 25 \\
\hline \multicolumn{5}{|c|}{ Total $(\mathrm{m})$} & 0.120198064 & 0.233600008 \\
\hline \multicolumn{5}{|c|}{ Mean $(\mathrm{m})$} & 0.004807923 & 0.009344 \\
\hline \multicolumn{5}{|c|}{ RMSEx (m) } & 0.069339185 & \\
\hline \multicolumn{5}{|c|}{ RMSEy $(\mathrm{m})$} & 0.096664369 & \\
\hline \multicolumn{5}{|c|}{$\operatorname{RMSEr}(\mathrm{m})$} & 0.118961855 & \\
\hline \multicolumn{5}{|c|}{ NSSDA Horizontal Accuracy 95\% Confidence Level (m) } & 0.205899178 & \\
\hline
\end{tabular}

Tabel 10. Hasil perhitungan RMSE vertikal

\begin{tabular}{llll}
\hline Point ID & Koordinat DSM $(\mathrm{m})$ & Koordinat ICP $(\mathrm{m})$ & Residual errors $(\mathrm{m})$ \\
\cline { 2 - 4 } & $\mathrm{z}$ & $\mathrm{z}$ & $\Delta \mathrm{z}^{2}$ \\
\hline ICP_1 & 608.7637269 & 609.2274 & 0.21499276 \\
ICP_2 & 611.0337517 & 611.30125 & 0.071555323 \\
ICP_3 & 603.8256142 & 603.9826 & 0.024644548 \\
ICP_4 & 613.3014706 & 614.416 & 1.242175884 \\
ICP_5 & 591.3215848 & 591.2675 & 0.002925171 \\
$\ldots \ldots$ & $\ldots$ & $\ldots$. & $\ldots$. \\
ICP_25 & 559.5830364 & 559.589 & $3.55647 \mathrm{E}-05$ \\
\hline Number check point & & 25 \\
\hline Total $(\mathrm{m})$ & & & 2.768798384 \\
\hline Mean $(\mathrm{m})$ & & 0.110751935 \\
\hline Rmsez $(\mathrm{m})$ & & 0.332794134 \\
\hline NSSDA vertical accuracy 95\% confidence level $(\mathrm{m})$ & & 0.652276502 \\
\hline
\end{tabular}

Berdasarkan hasil perhitungan uji validasi statistik, diperoleh hasil selisih elevasi, dan RMSEz paling kecil terdapat pada Tabel 12 dibandingan dengan Tabel 11. Dapat disimpulkan DTM hasil pengolahan software PCI Geomatica metode semi-otomatis filtering lebih presisi dan akurat dibandingkan dengan DTM hasil pengolahan software SAGA GIS metode otomatis filtering, karena memiliki elevasi yang kurang lebih sama dengan daerah sebenarnya dilapangan dalam hal ini data spotheight.

\subsubsection{Uji Validasi Non-Statistik (Visual)}

Pengolahan ini dilakukan dengan cara membandingkan tampilan atau visual DTM hasil pengolahan software SAGA GIS metode otomatis filtering dan DTM hasil pengolahan Software PCI Geomatica metode semi-otomatis filtering, dengan DTM Spotheight Topografi hasil pengolahan menggunakan sebuah software pemetaan. Uji visual DTM ini menggunakan metode profil melintang yang bertujuan untuk mengetahui beda tinggi atau tinggi rendahnya tanah sepanjang garis melintang yang dijadikan sampel area dalam pengujian ini. Area yang dipilih adalah area yang memiliki elevasi bervariasi, mencakup area DAS, dan perbukitan.

Uji perbandingan visual profil melintang DTM, dilakukan pada daerah yang sama yaitu dengan membuat garis melintang yang diawali dari posisi titik A (X:649154.526, Y:9129259.314) ke posisi titik B (X:649433.864, Y:9128973.079) sampel area ini dipilih karena merupakan area yang memiliki elevasi yang bervariasi dikarenakan mencakup area DAS dan perbukitan dengan Panjang profil melintang $400 \mathrm{~m}$, seperti tersaji pada Gambar 15 dan 16. 


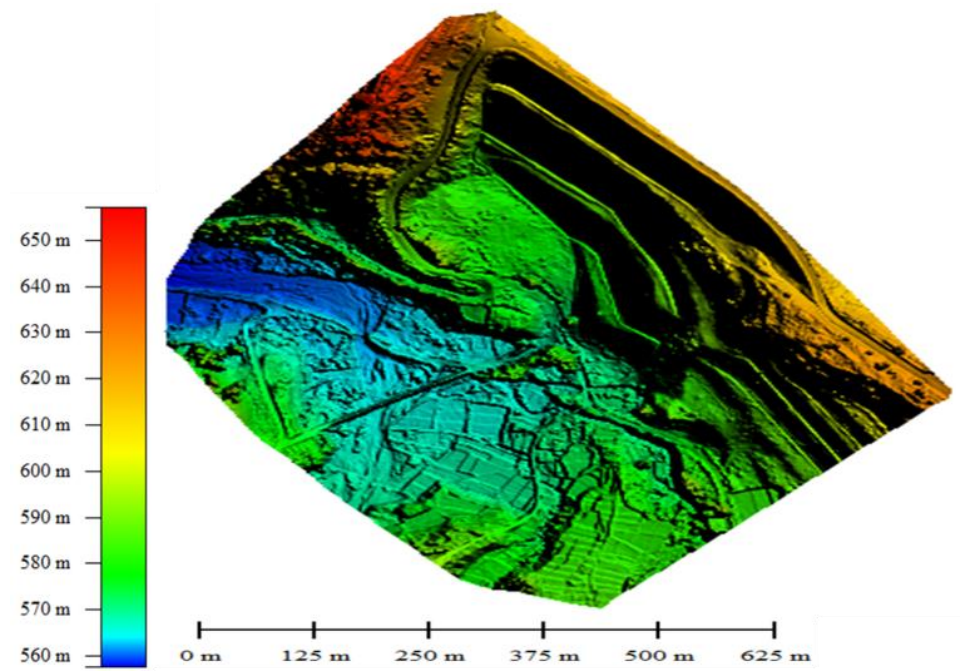

Gambar 12. Hasil DTM dari software SAGA GIS metode otomatis Filtering

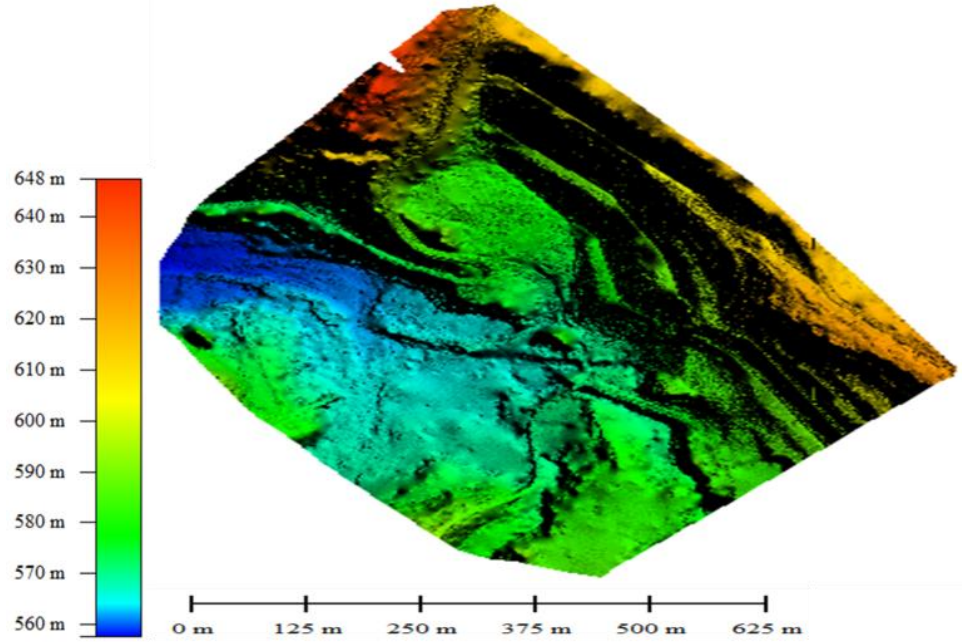

Gambar 13. Hasil DTM dari software PCI geomatics metode semi-otomatis Filtering

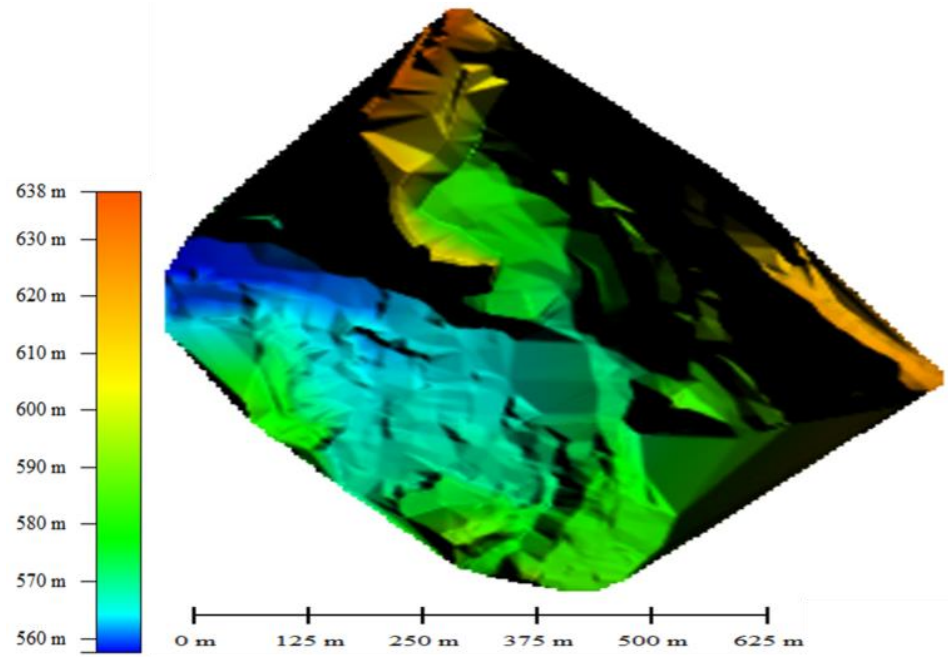

Gambar 14. Hasil DTM spotheight topografi

Perbedaan elevasi paling besar terdapat pada titik 1 yaitu pada jarak $50 \mathrm{~m}$ dari arah posisi titik A. Selisih elevasi sekitar $1 \mathrm{~m}$ dilihat dari elevasi DTM hasil software SAGA GIS metode otomatis filtering DTM sebesar $564 \mathrm{~m}$ terhadap elevasi DTM spotheight topografi sebesar $563 \mathrm{~m}$. Titik 2 pada jarak $200 \mathrm{~m}$ dari arah posisi titik A dengan selisih elevasi sekitar $5 \mathrm{~m}$ dilihat dari elevasi DTM hasil 
software SAGA GIS metode otomatis filtering DTM sebesar $570 \mathrm{~m}$ terhadap elevasi DTM spotheight topografi sebesar $565 \mathrm{~m}$ (Gambar 15). Jika dibandingkan dengan perbedaan elevasi terbesar pada Gambar 15, untuk Gambar 16 diposisi yang sama di titik 1. Jarak $50 \mathrm{~m}$ dari arah posisi titik A, selisih elevasi sekitar $0.5 \mathrm{~m}$ dilihat dari elevasi DTM hasil software PCI Geomatica metode semiotomatis filtering sebesar $563.5 \mathrm{~m}$ terhadap elevasi DTM spotheight topografi sebesar $563 \mathrm{~m}$. Titik 2 pada jarak $200 \mathrm{~m}$ dari arah posisi titik A dengan selisih elevasi sekitar $0.5 \mathrm{~m}$ dilihat dari elevasi DTM hasil software PCI Geomatica metode semi-otomatis filtering sebesar $565.5 \mathrm{~m}$ terhadap elevasi DTM spotheight topografi sebesar $565 \mathrm{~m}$.

Berdasarkan hasil uji validasi non-statistik (visual) diperoleh selisih elevasi, paling kecil terdapat pada Gambar 16 dibandingan dengan Gambar 15. Hal tersebut disebabkan pengolahan DTM menggunakan SAGA GIS metode otomatis filetering, masih meninggalkan unsur vegetasi atau penapisan yang kurang halus, sehingga objek yang harusnya dihilangkan teridentifikasi sebagai bentuk ground sehingga tidak dihilangkan. Pengolahan DTM menggunakan PCI Geomatica metode semi-otomatis filtering penapisannya lebih halus, sehingga lebih menyerupai bentuk ground pada daerah sebenarnya yaitu dalam hal ini DTM spotheight topografi.

Tabel 11. Hasil selisih elevasi dan RMSEz DTM hasil pengolahan software SAGA GIS metode otomatis filtering terhadap data spotheight

\begin{tabular}{|c|c|c|c|c|c|}
\hline \multirow{3}{*}{ No } & \multirow{3}{*}{ Point ID } & \multicolumn{2}{|c|}{ Koordinat DTM } & \multirow{3}{*}{$\begin{array}{l}\text { Selisih } \\
\text { elevasi (m) }\end{array}$} & \multirow{3}{*}{$\begin{array}{l}\text { Residual } \\
\text { errors (m) }\end{array}$} \\
\hline & & \multirow{2}{*}{$\begin{array}{l}\text { Spotheight } \\
\mathrm{Z}(\mathrm{m})\end{array}$} & \multirow{2}{*}{$\begin{array}{l}\text { Software metode } \\
\text { pengolahan otomatis } \\
\mathrm{Z}(\mathrm{m})\end{array}$} & & \\
\hline & & & & & \\
\hline 1 & DTL & 606.1441294 & 605.6616569 & 0.482472451 & 0.232779666 \\
\hline 2 & DTL & 608.4272534 & 608.0204625 & 0.406790886 & 0.165478825 \\
\hline 3 & DTL & 612.5202772 & 611.637006 & 0.883271203 & 0.780168018 \\
\hline 4 & DTL & 608.582518 & 608.523099 & 0.059418989 & 0.003530616 \\
\hline 5 & DTL & 611.7284916 & 611.3750265 & 0.353465093 & 0.124937572 \\
\hline $\begin{array}{l}\ldots \\
1454\end{array}$ & $\begin{array}{l}\ldots \\
\text { DTL }\end{array}$ & $\ldots 100034244$ & 5862614672 & 23.74195717 & 563.6805305 \\
\hline \multicolumn{3}{|c|}{ Jumlah titik referensi } & & 1454 & \\
\hline \multicolumn{2}{|c|}{ Total } & & & 1929.460711 & 22807.93035 \\
\hline \multicolumn{2}{|c|}{ Mean } & & & 1.327001865 & 15.68633449 \\
\hline \multicolumn{2}{|c|}{ RMSEz } & & & & 3.960597745 \\
\hline
\end{tabular}

Tabel 12. Hasil selisih elevasi dan RMSEz DTM hasil pengolahan software PCI geomatica metode semi-otomatis filtering terhadap data Spotheight

\begin{tabular}{|c|c|c|c|c|c|}
\hline \multirow{3}{*}{ No } & \multirow{3}{*}{ Point ID } & \multicolumn{2}{|c|}{ Koordinat DTM } & \multirow{3}{*}{$\begin{array}{l}\text { Selisih } \\
\text { elevasi (m) }\end{array}$} & \multirow{3}{*}{$\begin{array}{l}\text { Residual } \\
\text { errors (m) }\end{array}$} \\
\hline & & Spotheight & $\begin{array}{l}\text { Software metode } \\
\text { pengolahan semi- } \\
\text { otomatis }\end{array}$ & & \\
\hline & & $\mathrm{Z}(\mathrm{m})$ & $\mathrm{Z}(\mathrm{m})$ & & \\
\hline 1 & DTL & 606.1441294 & 605.9633231 & 0.18080628 & 0.032690911 \\
\hline 2 & DTL & 608.4272534 & 608.2515653 & 0.175688093 & 0.030866306 \\
\hline 3 & DTL & 612.5202772 & 612.3467067 & 0.173570478 & 0.030126711 \\
\hline 4 & DTL & 608.582518 & 608.1889299 & 0.39358806 & 0.154911561 \\
\hline 5 & DTL & 611.7284916 & 611.6596277 & 0.068863897 & 0.004742236 \\
\hline$\ldots$ & $\ldots$ & $\ldots$ & $\ldots$ & & \\
\hline 1454 & DTL & 610.0034244 & 583.8506185 & 26.1528059 & 683.9692564 \\
\hline Juml & titik refere & & & 1454 & \\
\hline Total & & & & 1816.965467 & 18244.79859 \\
\hline Mear & & & & 1.249632371 & 12.54800453 \\
\hline RMS & & & & & 3.542316267 \\
\hline
\end{tabular}




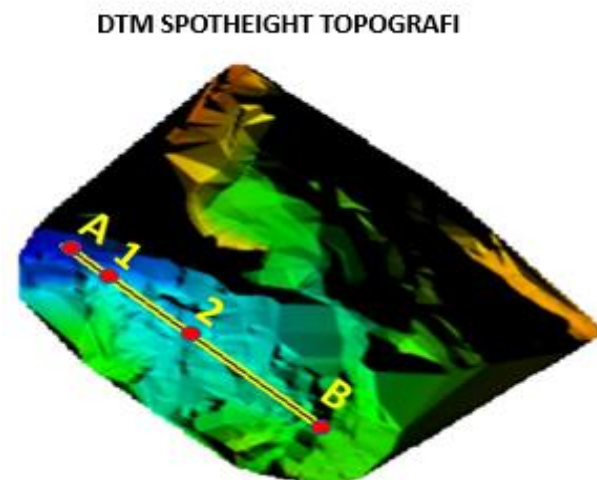

From Pos: $649154.526,9129259.314$
DTM METODE OTOMATIS FILTERING

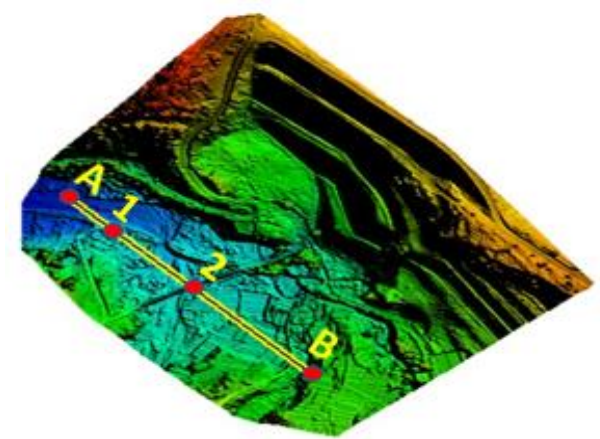

To Pos: $649433.864,9128973.079$

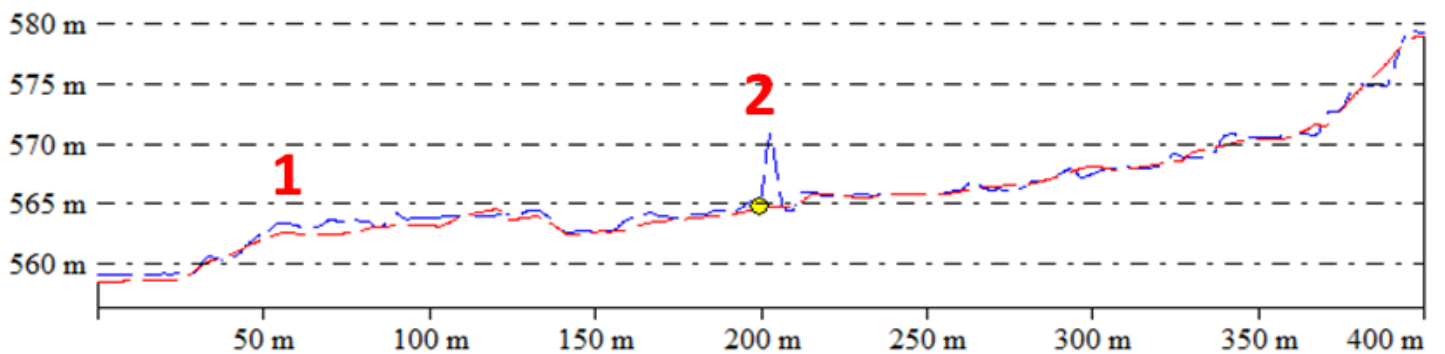

Gambar 15. Perbandingan visual profil melintang DTM hasil pengolahan dari software SAGA GIS metode otomatis filtering (garis putus-putus warna biru) dengan DTM spotheight topografi (garis putus-putus warna merah)

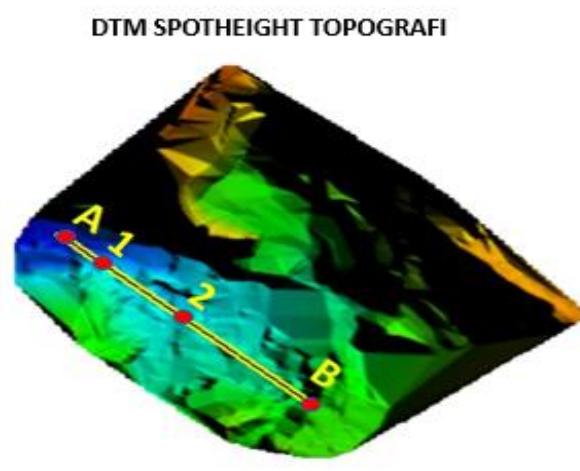

From Pos: $649154.526,9129259.314$

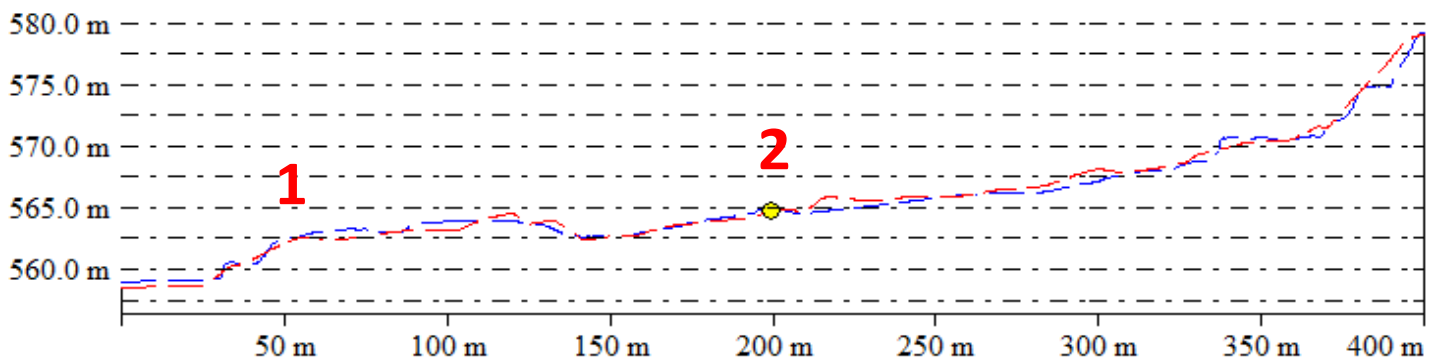

DTM METODE SEMI-OTOMATIS FILTERING

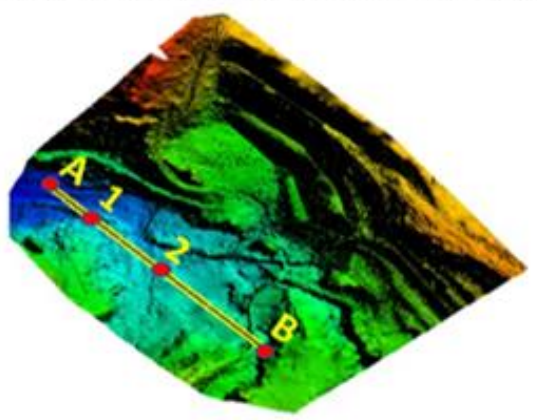

To Pos: $649433.864,9128973.079$ 
metode pengolahan otomatis filtering. Hal ini dibuktikan dengan Uji Validasi Statistik dan Uji Validasi Non-Statistik (Visual). Pada Uji Validasi Statistik untuk DTM hasil dari software PCI Geomatica mempunyai Selisih Elevasi sebesar $1.249 \mathrm{~m}$ dan RMSEz sebesar $3.542 \mathrm{~m}$ terhadap data spotheight, sedangkan DTM hasil dari software SAGA GIS mempunyai selisih Elevasi sebesar 1.327 m dan RMSEZ sebesar 3.960 m terhadap data Spotheight. Kemudian pada Uji Validasi NonStatistik (Visual) dilakukan dengan menggunakan metode profil melintang. Perbandingan profil melintang berdasarkan sample yang telah dibuat, pada titik yang sama perbedaan ketingian/elevasi terhadap DTM Spotheight paling kecil didapatkan dari DTM hasil dari software PCI Geomatica yaitu sebesar $0.5 \mathrm{~m}$ pada titik 1 dan pada titik 2 sebesar $0.5 \mathrm{~m}$, sedangkan pada DTM hasil dari software SAGA GIS pada titik 1 sebesar $1 \mathrm{~m}$ dan pada titik nomor 2 sebesar $5 \mathrm{~m}$.

\section{REFERENSI}

ASPRS. (2015). Positional Accuracy Standards for Digital Geospatial Data. Photogrammetric Engineer and Remote Sensing, 81(3), A1-A26.

BIG. (2020). Peraturan Badan Informasi Geospasial Republik Indonesia Nomor 1 Tahun 2020 Tentang Standar Pengumpulan Data Geospasial Dasar Untuk Pembuatan Peta Dasar Skala Besar.

Duantari, N., \& Cahyono, B. A. (2017). Analisis Perbandingan DTM (Digital Terrain Model) dari LIDAR (Light Detection and Ranging) dan foto udara dalam pembuatan kontur peta rupa bumi Indonesia. Jurnal Teknik ITS, 6(2), A699-A703

Fauzan, M. R. M., Jupri., \& Ridwana, R. (2021). Pengukuran Topografi Untuk Pembangunan Penampungan Air Bersih (Studi Kasus: Daerah Rajamandala, Kabupaten Bandung Barat). Jurnal Pendidikan Dan Ilmu Geografi, 6(1), 35-48.

Franstein K. J. B., Prasetyo, Y., \& Sukmono, A. (2019). Aalisis Akurasi DTM Hasil Ekstraksi Data Pemetaan Airborne Lidar Skala Besar Menggunakan Algoritma Cloth Simulation Filtering, Parameter-Free Ground Filtering Dan Simple Morphological Filtering Terhadap Slope Based Filtering. Jurnal Geodesi Undip, 8(4), 195-204.

Harfan, A., Yudhatama, D., \& Bachrodin, I. (2019). Pemanfaatan Metode Fotogrametri Untuk Pengukuran Garis Pantai Dan Identifikasi Objek-Objek Tematik Dengan Menggunakan Wahana UAV (Unmanned Aerial Vehicle) (Studi Kasus Pengukuran Garis Pantai Di Pangkalan TNI AL Pondok Dayung). Jurnal Chart Datum, 5(1), 71-84.

Khomsin., Anjasmara, M. I., \& Romadhon, R. (2019). Analisis Ketelitian Hasil Pengamatan GNSS Metode Radial Berdasarkan Lama Pengamatan Untuk Efisiensi Pengukuran Ground Control Point. Geoid Journal Of Geodesy And Geomatics, 15(1), 89-96.

Martiana, N. D., Prasetyo, Y., \& Wijaya, P. A. (2017). Analisis Akurasi DTM Terhadap Penggunaan Data Point Clouds Dari Foto Udara Dan LAS Lidar Berbasis Metode Penapisan Slope Based Filtering Dan Algoritma Macro Terrasolid. Jurnal Geodesi Undip, 6(1), 293-302.

Muhammad, M., \& Tahar, N. K. (2021). Comprehensive Analysis of UAV Flight Parameters for High Resolution Topographic Mapping. IOP Conf. Series: Earth and Environmental Science, 767, 1-6. doi:10.1088/1755-1315/767/1/012001.

Pepe, M., Costantino, D., Alfio, S. V., Cartellino, E., \& Vozza, G. (2021). A Novel Method Based on Deep Learning, GIS and Geomatics Software for Building a 3D City Model from VHR Satellite Stereo Imagery. ISPRS International Journal Of Geo-Information, 10(697), 1-17.

Putra, P. D. (2016). Pembuatan Peta Orthophoto Pemotretan Udara Dengan Fixed Lens Menggunakan Pesawat UAV (Unmanned Aerial Vehicle). Skripsi. Teknik Geodesi, Institut Teknologi Nasional, Malang.

Riadi, S. (2015). Pembuatan Peta Topografi Skala Besar Secara Fotogrametris Dengan Memanfaatkan Foto Udara UAV Kamera Non-Metrik. Skripsi. Teknik Geodesi, Institut Teknologi Nasional, Malang.

Wirantiko, M., Handayani, H. H., \& Cahyono, B. A. (2021). Studi Pembuatan DTM Menggunakan Metode Slope Based Filtering dan Grid Based Filtering (Studi Kasus: Kelurahan Wonokromo Dan Lontar, Kota Surabaya). Geoid Journal Of Geodesy And Geomatics, 16(1), 46-56. 